\title{
Surface water temperature, salinity, and density changes in the northeast Atlantic during the last 45,000 years: Heinrich events, deep water formation, and climatic rebounds
}

\author{
M. A. Maslin ${ }^{1}$ and N. J. Shackleton \\ Godwin Laboratory, University of Cambridge, Cambridge, England \\ U. Pflaumann \\ Geologisch Paläontologisches Institut, Universität Kiel, Kiel, Germany
}

\begin{abstract}
We developed a new method to calculate sea surface salinities (SSS) and densities (SSD) from planktonic foraminiferal $\delta^{18} \mathrm{O}$ and sea surface temperatures (SST) as determined from planktonic foraminiferal species abundances. SST, SSS, and SSD records were calculated for the last 45,000 years for Biogeochemical Oceanic Flux Study (BOFS) cores 5K and 8K recovered from the northeast Atlantic. The strongest feature is the dramatic drop in all three parameters during the Heinrich "ice-rafting" events. We modelled the possibility of deepwater formation in the northeast Atlantic from the SSD records, by assuming that the surface waters at our sites cooled as they flowed further north. Comparison with modelled North Atlantic deepwater densities indicates that there could have been periods of deepwater formation between 45,000 and $30,000{ }^{14} \mathrm{C}$ years B.P. (interrupted by iceberg meltwater input of Heinrich event 3 and 4, at 27,000 and 38,000 ${ }^{14} \mathrm{C}$ years B.P.) and during the Holocene. No amount of cooling in the northeast Atlantic between 30,000 and 13,000 years could cause deep water to form, because of the low salinities resulting from the high meltwater inputs from icebergs. Our records indicate that after each Heinrich event there were periods of climatic rebound, with milder conditions persisting for up to 2000 years, as indicated by the presence of warmer and more saline water masses. After these warm periods conditions returned to average glacial levels. These short term cold and warm episodes in the northeast Atlantic are superimposed on the general trend towards colder conditions of the Last Glacial Maximum (LGM). Heinrich event 1 appears to be unique as it occurs as insolation rose and was coeval with the initial melting of the Fennoscandian ice sheet. We propose that meltwater input of Heinrich event 1 significantly reduced North Atlantic Deep Water formation, reducing the heat exchange between the low and high latitudes, thus delaying deglaciation by about 1500 radiocarbon years (2000 calendar years).
\end{abstract}

\section{Introduction}

At present, the surface waters in the North East Atlantic are dominated by the Gulf Stream. Its warm, saline waters flow from the Gulf of Mexico across the North Atlantic and into the Norwegian Sea, while the cold, low-salinity polar surface waters are restricted to the far northwest Atlantic. The northward flow of warm saline waters from the tropical and subtropical Atlantic to higher latitudes is instrumental in the formation of North Atlantic Deep Water (NADW). Cooling of the surface waters during northward transportation increases their density until a critical value; then they sink in the Greenland Sea and form the NADW.

'Now at Geologisch Paläontologisches Institut, Universität Kiel, Kiel, Germany, and Department of Geography, University College London, London, England.

Copyright 1995 by the American Geophysical Union.

Paper number 94PA03040.

0883-8305/95/94PA03040\$10.00
During the last glacial, surface water circulation in the North Atlantic was dominated by an anticlockwise polar gyre [Ruddiman and McIntyre, 1976; Grousset et al. 1993; Robinson et al, 1995]. The dominant surface water current in the northeast Atlantic during the Last Glacial Maximum (LGM) was the lateral west to east polar current at $40^{\circ}-45^{\circ} \mathrm{N}$, originating in the Labrador and Greenland Seas, and the northward progression of this current between $15^{\circ}$ and $20^{\circ} \mathrm{W}$ [Ruddiman and McIntyre, 1976; Ruddiman, 1977; Robinson et al., 1995]. There was, however, significant iceberg debris deposition south of Iceland $\left(63^{\circ} \mathrm{N}\right)$, during the LGM [Fillon et al,. 1981; Fillon, 1985] suggesting that southern subtropical surface water frequently intruded into the northeast Atlantic and promoted iceberg melting.

This anticlockwise polar gyre transported icebergs from the Laurentide icesheet into the northeast Atlantic throughout the last glacial, as shown by records of the short periods of intense icebergs production (so called Heinrich events) in the northeast Atlantic [Ruddiman, 1977; Heinrich, 1988; Broecker et al., 1992; Bond et al., 1992; Grousset et al., 1993]. We document sea surface temperature (SST), salinity 
Table 1. Site Data for the Northeast Atlantic Cores Selected from RRS Discovery Cruise 184, Biogeochemical Ocean Flux Study (BOFS) $1989 \operatorname{Leg} 3$ for this Study

\begin{tabular}{|c|c|c|c|c|c|}
\hline \multirow[b]{2}{*}{$\begin{array}{l}\text { Station } \\
\text { Number }\end{array}$} & \multirow[b]{2}{*}{ Core } & \multicolumn{2}{|c|}{ Position } & \multirow[b]{2}{*}{$\begin{array}{l}\text { Water } \\
\text { Depth, } \mathrm{m} \\
\end{array}$} & \multirow[b]{2}{*}{$\begin{array}{l}\text { Length of Core } \\
\text { Recovered, } m\end{array}$} \\
\hline & & $\begin{array}{l}\text { Latitude, } \\
\text {-N }\end{array}$ & $\begin{array}{c}\text { Longitude, } \\
\cdot W\end{array}$ & & \\
\hline 11882 & $5 K$ & $50^{\circ} 41.3^{\prime}$ & $21^{\circ} 51.9^{\prime}$ & 3547 & 2.63 \\
\hline 11886 & $8 \mathrm{~K}$ & $52^{\circ} 30.1^{\prime}$ & $22^{\circ} 04.2^{\prime}$ & 4045 & 2.46 \\
\hline 11891 & $11 \mathrm{~K}$ & $55 \cdot 11.5$ & $20^{\circ} 21.1^{\prime}$ & 2004 & 0.96 \\
\hline 11896 & $14 K$ & $58^{\circ} 37.2^{\prime}$ & $19^{\circ} 26.2^{\prime}$ & 1756 & 2.28 \\
\hline 11905 & $17 \mathrm{~K}$ & $58^{\circ} 00.2^{\prime}$ & $16^{\circ} 30.3^{\prime}$ & 1150 & 2.44 \\
\hline
\end{tabular}

(SSS), and density (SSD) changes at the northern BOFS sites $\left(50^{\circ}-60^{\circ} \mathrm{N}, 20^{\circ} \mathrm{W}\right.$; Table 1 and Figure 1$)$ in order to determine the varying influence of warm and surface cold currents and the effects of the Heinrich events on deepwater circulation.

\section{Sea Surface Temperature}

SST of the North Atlantic was first comprehensively reconstructed by the CLIMAP group [McIntyre et al., 1976; Climate: Long-Range Investigation and Prediction (CLIMAP) Project Members 1976 \& 1981] with the aim of reconstructing the surface water temperatures of the worlds oceans at the LGM $(18,000$ years B.P.), and to compare these to present day conditions. The SST was estimated using the Imbrie and Kipp (1971) transfer function method on different microfossil groups. In the North Atlantic, only the foraminiferal assemblages were used for paleotemperature reconstruction, because of the rarity of other microfossils and/or the domination of their assemblage by one species [CLIMAP Project Members, 1976]. CLIMAP results indicated a strong north-south temperature gradient in an east-west band between $40^{\circ}$ and $45^{\circ} \mathrm{N}$ in summer and winter at 18,000 years B.P. In contrast, at present in the North Atlantic, the cold polar waters $\left(<4^{\circ} \mathrm{C}\right)$ are restricted to a narrow band in the northwest Atlantic because the warm Gulf Stream influences much of the North Atlantic and the southern parts of the Norwegian Sea. CLIMAP results lacked fine-scale regional detail, and we aim to estimate SSTs at high spatial and temporal resolution, to build up a detailed regional picture of the water mass changes in the northeast Atlantic over the last 45,000 years.

\section{Statistical Estimation of Temperature}

BOFS cores $5 \mathrm{~K}, 8 \mathrm{~K}, 11 \mathrm{~K}, 14 \mathrm{~K}$, and $17 \mathrm{~K}$ were selected as having the best preservation, and were sampled every $2 \mathrm{~cm}$. The samples were disaggregated by soaking and gentle shaking in distilled water overnight, and then washed through a $63-\mu \mathrm{m}$ sieve. After washing, the coarse fraction was dried in an oven at $60^{\circ} \mathrm{C}$ and weighed. The size fraction $>150 \mu \mathrm{m}$ was split using Soiltest CL-242A, as many times as required to obtain a subsample of approximately 300 whole planktonic foraminifera. The final split was placed on a micropaleontological picking tray. All whole, or nearly whole planktonic foraminifera, were identified and counted using the CLIMAP group taxonomy [Kipp, 1976]. Any specimens which were not part of the 16 selected species were classified as "other". Figure 2 shows the relative abundance of planktonic foraminifera species versus ${ }^{14} \mathrm{C}$ age [Maslin, 1993; Manighetti et al., this issue] for BOFS 5K. BOFS 5K was selected for AMS ${ }^{14} \mathrm{C}$ dating as it had the best oxygen isotope stratigraphy indicating high sedimentation rates and no hiatusis for the last 45,000 years [Maslin, 1993]. The relative abundance data were used to calculate SST.

Quantitative methods have been widely used to analyze micropaleontological data to derive estimates of environmental parameters. The most widely used are those estimating the SSTs from planktonic foraminifera and other microfossil assemblage. A major assumption is that species abundance distributions are related systematically to one parameter of the environment in which they live [Imbrie and Kipp, 1971; Birks et al., 1990]. In most studies, faunal data are calibrated to only one environmental parameter in one equation. In doing so, one assumes that the species abundance of the planktonic foraminifera is solely, or dominantly, controlled by that one parameter. These two assumptions, a systematic relationship and dominant control by a single parameter, are conceptually different. In reality, every assemblage is jointly influenced linearly and/or nonlinearly by many factors such as nutrient availability, light intensity, interspecific competition, temperature, salinity, etc. [e.g., $B e$, 1977]. Different combinations of these controlling factors may lead to the same faunal composition. Another complication of quantitative methods is that the fossil data do not necessarily reflect the true living floating foraminiferal assemblage. Changes from the "true" assemblage may be caused by: differential transportation to the sediment, differential dissolution of species, bioturbation, sample splitting errors, and errors in species identification. Imbrie and Kipp (1971) regarded the chronological heterogeneity of core top samples, which could represent thousands of years, as the largest source of error in their transfer method. The final problem associated with the methods of estimating SSTs quantitatively is that the data are usually in a percentage and not an absolute form. This means that common species covary inversely, even without any inverse relationship in their absolute abundances, the "fixed sum" problem. These problems were monitored using the fragmentation ratio and 


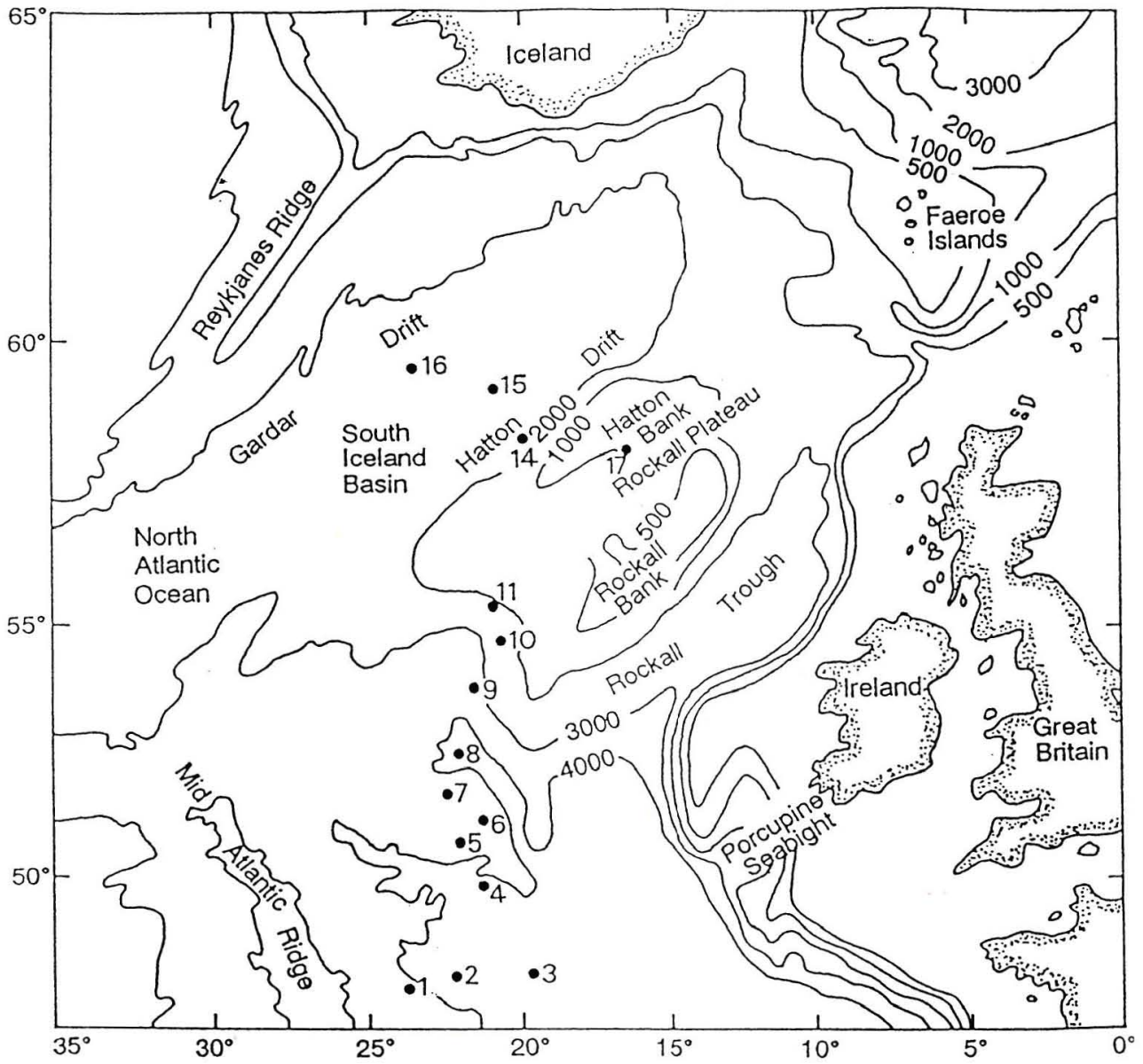

Figure 1. General location of the BOFS cores taken on RRS Discovery cruise Leg 3 (1989). The numbered locations refer to the Kastern core taken at that site. Water depth given in meters.

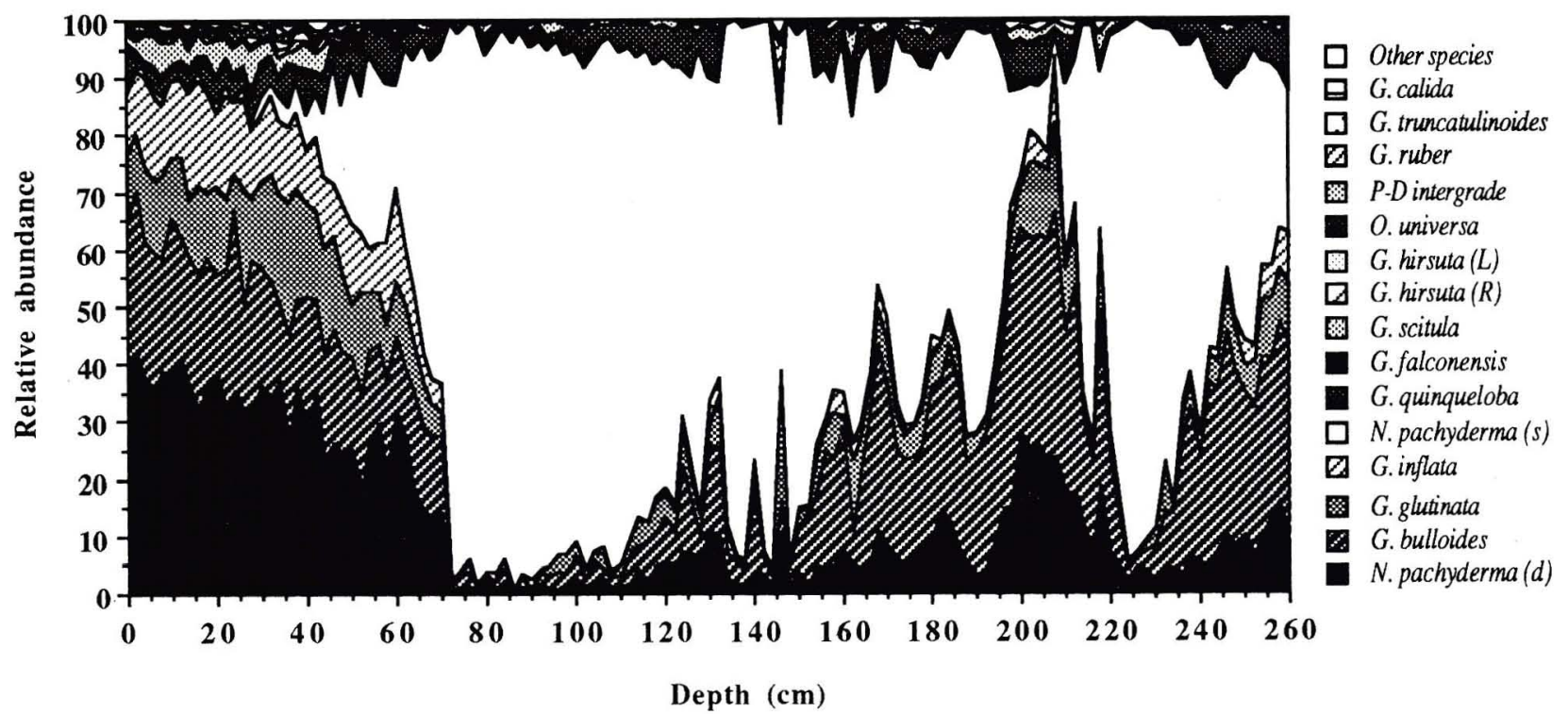

Figure 2. Relative abundance plot of the planktonic foraminifera species found in core BOFS 5K. 
the planktonic to benthic foraminifera ratio and were considered when interpreting the SSTs estimates. In this study two approaches were used to estimate SST, the Transfer Function (TF) method and the Modern Analog Technique (MAT).

The most extensively applied method of estimating SSTs has been the TF method as initiated by Imbrie and Kipp [1971]. An empirical equation is developed from the core top data set, which can then be applied downcore. The most successful application of this method has been in the Atlantic for which Imbrie and Kipp [1971] first developed the TF [Mix et al., 1986; Ruddiman et al., 1987; McIntyre et al., 1989]. Ruddiman and Esmay [1987) attempted to calibrate a TF with only four major temperature-sensitive species in the North Atlantic, to permit faster counting. Extensive reviews of the development of TF equations can be found in the works by Imbrie and Kipp [1971], Molfino et al. [1982], and Le [1991]. For the Biogeochemical Oceanic Flux Study (BOFS) cores we used the CLIMAP FA20 TF equation ocean-wide data set, calibrated for the entire Atlantic Ocean [Molfino et al., 1982].

The MAT calculates the similarity coefficients between a downcore sample and each of the core top samples [Hutson, 1979; Overpeck et al., 1985; Prell, 1985; Le, 1991]. From among all the core top samples, it selects then a subset of samples which are most similar to that downcore sample as modern analogues. The SST estimate of the core sample is obtained by averaging the SSTs of its modern analogues by either a weighted or unweighted approach. In the weighted solution, a sample with a larger similarity coefficient contributes more to the SST estimate. The advantages and disadvantages of MAT and TF method are discused at length by Prell [1985] and Le [1991]. To make "correct" SST estimates, a wide distribution of core-top samples is needed to sufficiently represent all possible conditions; otherwise some core samples may have no close modern analogues. For the BOFS cores, two different MATs were used: (1) MAT based on the original CLIMAP core top global data set, calculated by $\mathrm{J}$. Le and (2) MAT using the EPOCH core top regional data set,
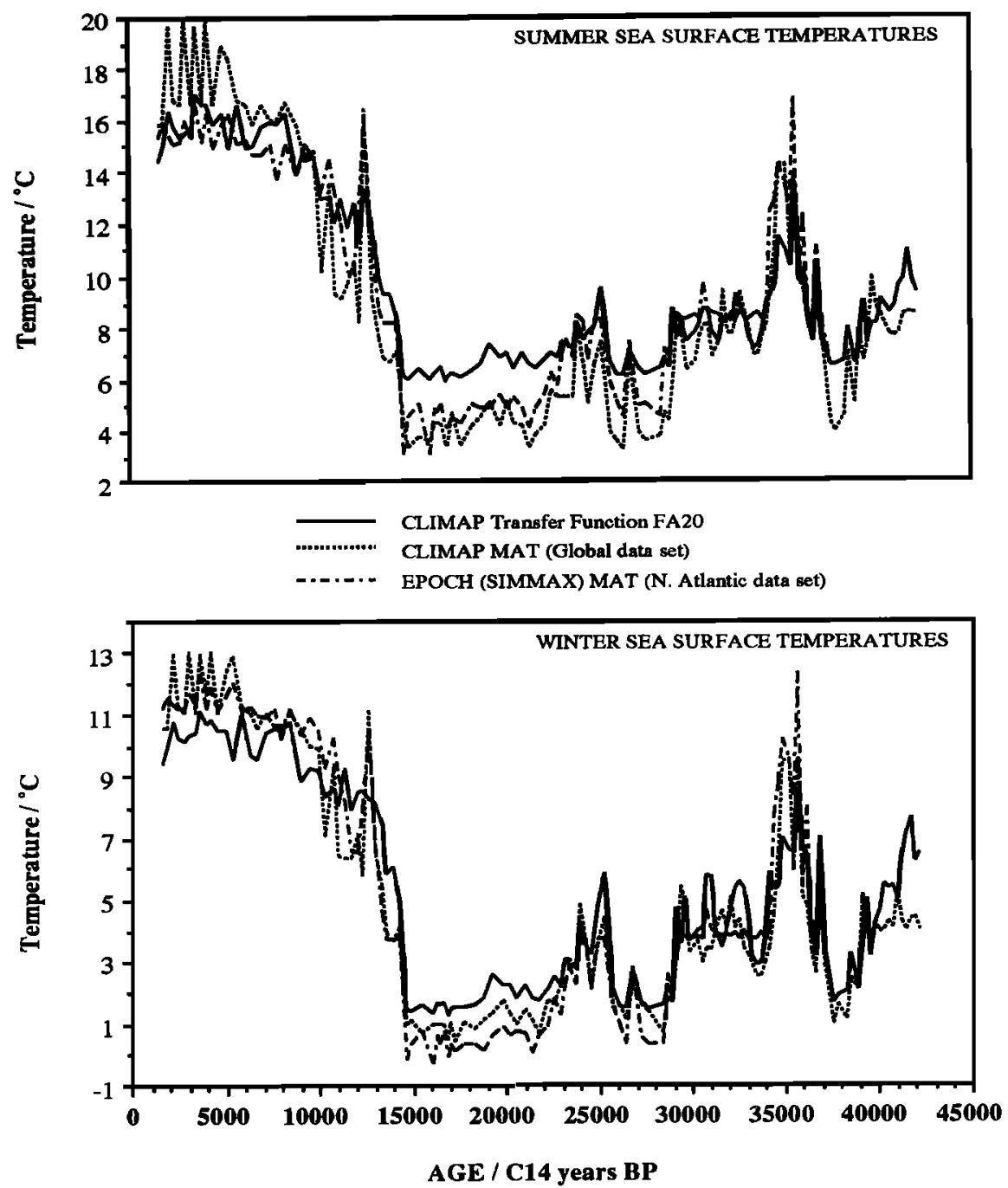

Figure 3. BOFS 5K: Comparison of the different estimates of sea surface temperatures using the same species counts. The estimates include CLIMAP transfer function equation FA20, CLIMAP modern analog technique (MAT) using a global database, and EPOCH (SIMMAX) MAT using a North Atlantic database [Pflaumann et al., 1992 also submitted manuscript, 1995]. 
calculated using the SIMMAX approach [Pflaumann et al., 1992, also SIMMAX, a transfer function technique to deduce Atlantic sea surface temperatures from planktonic foraminifera: the EPOCH approach, submitted to Paleoceanography, 1995 (hereinafter referred to as submitted manuscript, 1995)].

The three SST estimates for BOFS 5K show a maximum difference of more than $2^{\circ} \mathrm{C}$ (Figure 3 ). This is within the errors associated with the different estimates, which is about $\pm 1.2^{\circ} \mathrm{C}$ at the $80 \%$ confidence limit. Of the three estimates the CLIMAP MAT has the most variability, especially during warmer periods. This could be caused by the use of a small global database compared with the much larger regional EPOCH data base; or by the use of the P-D intergrade (an intermediate form between $N$. dutertrei and $N$. pachyderma (d) defined by $K i p p$ [1976] to reduce inconsistencies between different workers). The EPOCH MAT estimate does not use the P-D intergrade definition, and those specimens are combined with $N$. pachyderma (d) total [Pflaumann et al., 1992]. The glacial-Holocene SST range of the EPOCH $\left(0^{\circ}\right.$ to $\left.12^{\circ} \mathrm{C}\right)$ and the CLIMAP FA20 $\left(1.5^{\circ}\right.$ to $\left.11^{\circ} \mathrm{C}\right)$ estimates also differs, due to the increasing inaccuracies of all SST estimates as the foraminiferal assemblagse become increasingly monospecific. The largest SST differences occur between the CLIMAP FA20 and the CLIMAP MAT in the summer glacial but not in the winter estimates.

The results of the three different SST estimates are strikingly similar, the minor variations being caused by the difference in modern data sets as well as in methods of estimation. In this study, we used CLIMAP equation FA20 estimates because its estimates had the smallest range, minimising its effect on the salinity estimate. In addition, the results of this study are compared directly with CLIMAP and work based on it.

\section{SST Changes in the BOFS Sites during the Last 45,000 Years}

Figure 4 shows the summer and winter SST estimates for several BOFS cores versus ${ }^{14} \mathrm{C}$ age. The age models used in this study were developed by Maslin [1993] and are different to those of Manighetti et al. [this issue]. The reason for this difference is the great emphasis on the planktonic $\delta^{18} \mathrm{O}$ and $\delta^{13} \mathrm{C}$ compared to other sedimentary records to make them more compatible with other stable isotopes stratigraphies [e.g. Jansen and Veum, 1990; Duplessy et al., 1991, 1992]. Whole Core Magnetic Susceptibility (WCMS) documents the relative amount of ice-rafted debris in the BOFS cores [Maslin, 1993; Robinson et al., 1995] and was used to define the location of Heinrich zones 1 to 4 .

All the BOFS cores show a pronounced increase in SST at the last termination; in the cores with the high sedimentation rates we see the two step deglaciation. SSTs at 5K and 8K dropped significantly during Heinrich event 3 and 4. Between $\mathrm{H} 4$ and $\mathrm{H} 3$ (35-36 kyr B.P.) there is a peak in the SST in all the cores, but most intense in $5 \mathrm{~K}$, where the SST was $6^{\circ} \mathrm{C}$ higher than during $\mathrm{H} 4$ and $4^{\circ} \mathrm{C}$ higher than the average temperature between $\mathrm{H} 3$ and $\mathrm{H} 4$.

\section{Sea Surface Salinity}

Initial attempts to estimate salinity of surface waters were made using the transfer function approach [Imbrie and Kipp, 1971; Kipp 1976; Cullen, 1981]. This approach was found to be successful only in restricted regions, such as the Arabian Sea, with a high gradient pattern of salinity which was highly correlated to one of the foraminiferal factors [Cullen, 1981].

There are two major reasons for the general failure of the transfer function method of estimating sea surface salinity (SSS): 1 . both in laboratory culture and in the open ocean

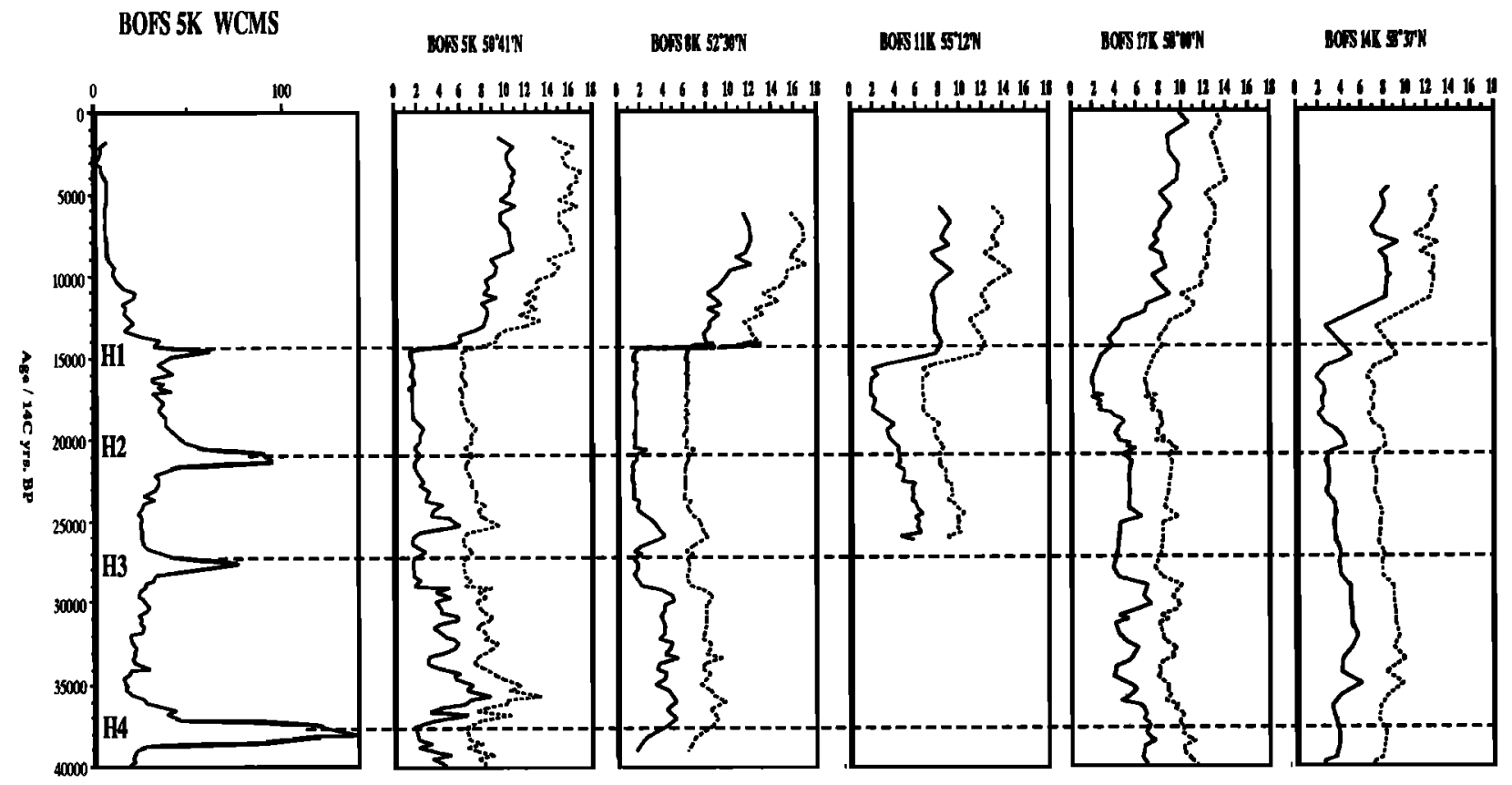

Figure 4. Summer and winter sea surface temperatures for the BOFS cores estimated using the CLIMAP TF FA20. Age model from Maslin [1993]. Dotted lines represent the Heinrich events as defined by the whole core magnetic susceptibility (WCMS) of BOFS 5K [Maslin, 1993]. 
salinity has little relative effect on the growth or distribution of planktonic foraminifera. It has even been demonstrated that $N$. pachyderma ( $s$ ) can survive and flourish within sea ice and in the surrounding extremely low salinity waters of the Antarctic [Spindler and Dieckmann, 1986; Dieckmann et al., 1991]. 2. Salinity is usually related to SST (Duplessy et al. [1991] using the data from Geochemical Ocean Sections Study (GEOSECS) [1987]). It is thus very difficult to reconstruct SSS by the transfer function method in the midlatitutes, because SST is the dominant control on the distribution of the foraminifera, and salinity is not independent.

Another approach to estimating sea surface salinity is to extract the information from $\delta^{\mathbf{1 8}} \mathrm{O}$ of planktonic foraminifera, as first tried by Fillon and Williams [1984], who estimated the meltwater discharge of the Laurentide icesheet into the Labrador Sea and the Gulf of Mexico. Duplessy et al. [1991, 1992] used a different approach, also based on the $\delta^{18} \mathrm{O}$ of planktonic foraminifera, to estimate surface water salinity for the LGM for the North Atlantic. They relied heavily on calibration using the GEOSECS [1987] and core top data sets. GEOSECS data are limited because there was only one northsouth transect in the North Atlantic (March - October). Core top data have inherent inaccuracies due to the assumption that the core top represents the present day. The BOFS cores in this study show that the age of the core tops can vary from between 0 and 6000 years B.P. (Manighetti et al., this issue), due to bioturbation and the relative success of recovering intacted core tops. In this study we therefore present an alternative method which relies less on such calibrations.

\section{Estimating Sea Surface Salinity Downcore}

The $\delta^{18} \mathrm{O}$ of the calcite test of planktonic foraminifera is controlled by the $\delta^{18} \mathrm{O}$ of the surrounding water, and the temperature at which it is formed. The $\delta^{18} \mathrm{O}$ of the surface water $\left(\delta_{w}\right)$ is controlled by the salinity of the surface waters which is influenced by (1) global ice volume, (2) precipitation/evaporation regime of the area, and (3) river or meltwater input. We tried to remove the temperature effect and the global ice volume effect from the $\delta^{18} \mathrm{O}$ of planktonic foraminifera to estimate localized salinity changes.

The isotopic fractionation factor of oxygen between $\mathrm{CaCO}_{3}$ - $\mathrm{H}_{2} \mathrm{O}$ was calculated using equation (1) proposed by $\mathrm{O}^{\prime} \mathrm{Neil}$ et al. [1969] and Shackleton [1974].

or

$$
1000 \ln \alpha_{c-w}=2.78\left(10^{6} \mathrm{~T}^{-2}\right)-3.39
$$

$$
\alpha_{c-w}=\exp \left[0.00278\left(10^{6} T^{-2}\right)-0.00339\right]
$$

where $\alpha_{c-w}$ is the isotopic fractionation factor of oxygen between $\mathrm{CaCO}_{3}$ and $\mathrm{H}_{2} \mathrm{O}, \mathrm{T}$ is the temperature of the ambiant surface waters in Kelvin $\left(T^{*}+273.16\right)$, and $T^{*}$ is the effective temperature of calcification defined for each planktonic foraminiferal species [Duplessy et al., 1991, 1992].

The isotopic fractionation factor between calcite (c) and water (w) is defined as

$$
\alpha_{c-w}=\left(1+10^{-3} \delta_{c}\right) /\left(1+10^{-3} \delta_{w}\right)
$$

where $\delta_{c}$ is $\delta^{18} O$ of calcite, and $\delta_{w}$ is $\delta^{18} O$ of water.
To calculate the $\delta_{W}$ of surface waters the equation can be rewritten:

$$
\delta_{w}=\left\{\left(1000+\delta_{c}\right) / \alpha_{c-w}\right\}-1000
$$

where $\delta_{\mathrm{c}}$ is the $\delta^{18} \mathrm{O}$ of the planktonic foraminifera in SMOW (see equation 5) and $\alpha_{\mathrm{c}-\mathrm{w}}$ is the isotopic fractionation factor of oxygen between calcite and water calculated in equation (2). The conversion of the planktonic foraminifera $\delta^{18} \mathrm{O}$ records from the PDB (belemnite from the Peedee Formation, South Carolina) isotopic scale to that of V-SMOW (Vienna-Standard Mean Ocean Water) was done using the Coplen et al. [1983] equation:

$$
\delta^{18} \text { OV-SMOW }=1.03091 \delta^{18} \text { OPDB }+30.91
$$

We used the North Atlantic temperature calibrations of Duplessy et al. [1991, 1992] to estimate the ambient surface water temperature (T). For each species, Duplessy et al. [1991, 1992] calibrated the summer SST from the CLIMAP core top data set with the isotopic temperature calculated from the $\delta^{18} \mathrm{O}$ records for the whole of the North Atlantic. They were thus able to correct the summer SST and obtained the effective temperature of calcification $\left(T^{*}\right)$ for each species (equations 6 and 7).

$$
\text { G. bulloides } \quad \mathrm{T}^{*}=\text { summer SST }-1^{\circ} \mathrm{C} \quad 7^{\circ}-22^{\circ} \mathrm{C}
$$

$N$. pachyderma (s) $\mathrm{T}^{*}=$ summer SST $-2.5^{\circ} \mathrm{C} \quad 3^{\circ}-10^{\circ} \mathrm{C}$

The effective temperature of calcification ( $T^{*}$ ), based on the CLIMAP FA20 temperature estimates, for each species was then used as the ambient surface water temperature ( $T$ ) to calculate $\delta_{\mathrm{w}}$ (equation 2 ). To estimate a complete downcore record of summer salinity, we combined the $\delta_{w}$ records of $G$. bulloides and $N$. pachyderma (s) based on the optimum temperature ranges suggested by Duplessy et al. [1991]. At SSTs greater than $10^{\circ} \mathrm{C}$ the calculated summer $\delta_{\mathrm{w}}$ record of $G$. bulloides was used, at SSTs less than $7^{\circ} \mathrm{C}$ the summer $\delta_{\mathrm{w}}$ record of $N$. pachyderma (s), and between $7^{\circ}$ and $10^{\circ} \mathrm{C}$ the average of the $G$. bulloides and $N$. pachyderma (s) $\delta_{\mathrm{w}}$ record.

The next stage in the calculation of SSS is the removal of the global salinity effect caused by changes in the global ice volume. The best estimate of the changes in the volume of the continental icesheets is derived from the sea level curve based on dated coral reefs drilled off-shore of Barbados [Fairbanks, 1989; Bard et al., $1990 \mathrm{a}, \mathrm{b}$, with ${ }^{14} \mathrm{C}$ accelerator mass spectrmeter (AMS) dates go back to $18,200 \pm 400$ years B.P. with a resolution of 100 to 1300 years. Recent estimates for the conversion of sea level to $\delta^{18} \mathrm{O}$ changes in the surface waters have ranged from $0.011 \%$ o/m to $0.013 \%$ o/m [Labeyrie et al., 1987; Shackleton, 1987; Fairbanks, 1989]. Duplessy et al. [1991] adopted a mean value $0.012 \% / \mathrm{m}$, which we also used.

The sea level record only goes back to 18,200 years, whereas the lowest samples from the BOFS cores have an age of 58,000 years. To extend the global ice volume $\delta^{18} \mathrm{O}$ record back in time, we selected two oceanic cores from the Pacific, TR163-31B (3.37.2'S, 83.58' $\mathrm{W}$, in a water depth of $3210 \mathrm{~m}$ ) and V19-30 (3.21'S, 83.21'W, in a water depth $3091 \mathrm{~m})$. 
These cores are in very close proximity and in the tropics, so we expect that the local changes in SST and salinity due to changes in the precipitation/evaporation regimes were minimal. Core TR163-31B has a reliable age model based on $23{ }^{14} \mathrm{C}$ AMS dates on planktonic foraminifera [Shackleton et $a l$., 1988]. To represent the global $\delta_{\mathrm{W}}$ changes in the oceans in the past, we used the $\delta^{18} \mathrm{O}$ record of the benthic genus Uvigerina. This record was added to the Barbados $\delta^{18} \mathrm{O}$ curve extending it to 31,360 years B.P. Core TR163-31B does not extend back as far as Heinrich event 4 . To extend the record further back, the Uvigerina $\delta^{18} \mathrm{O}$ (minus the present day $\delta^{18} \mathrm{O}$ ) record from core V19-30 was used. The age model for V19-30 is orbitally calibrated to calendar years [Shackleton and Pisias, 1985]. As the ${ }^{14} \mathrm{C}$-calendar years calibration does not extend further than $25 \mathrm{kyrs}$ [Bard et al., 1990a,b], it was assumed that calendar years from 32 to $58 \mathrm{kyr}$ B.P. were the same as ${ }^{14} \mathrm{C}$ years B.P. [Stuiver and Reimer, 1993].

To correct the $\delta_{w}$ record for ice volume variations, the chronologies of all records were made compatible: a Gaussian interpolation using weighted duplicates was applied to the records with a sample spacing of 200 years and a window size of 1198 years. The $\delta_{w}$ was corrected by subtracting the ice volume isotopic effect from the raw $\delta_{w}$. To convert the corrected $\delta_{W}$ to salinity (\%o), we assumed that the freshwater input (zero salinity) had an oxygen isotopic composition of $-20 \%$, the isotopic composition of snow entering and leaving the present Arctic ice sheet, assuming mass balance equilibrium [Craig and Gordon, 1965; Shackleton, 1967a; Mix and Ruddiman, 1984]. The $\delta^{18} \mathrm{O}$ of mean annual precipitation at Baffin Island and the Labrador Sea (believed to be indicative of conditions in the North Atlantic during the last glacial [International Atomic Energy Agency (IAEA), 1981]) varies between -15 and $-20 \%$ in isotopic composition. The calibration of Duplessy et al. [1991] for the modern relationship between $\delta_{\mathbf{w}}$ to salinity in the North Atlantic from the GEOSECS [1987] data gives a similar end-member of $-19.264 \%$. The equation, assuming an end-member of $-20 \%$, is

$$
\mathrm{S}=\mathrm{S}_{\mathrm{m}}+\mathrm{S}_{\mathrm{v}}+1.735 \delta_{\mathrm{w}}^{*}
$$

where $S$ is Salinity $\%, S_{\mathrm{m}}$ is Present mean ocean salinity, $34.74 \%$ [GEOSECS , 1987], $\delta_{\mathrm{w}}{ }^{*}=\delta_{\mathrm{w}}$ anomaly $\left(\delta_{\mathrm{w}}\right.$ [sample] $-\delta_{w}$ [modern] ) $/ \%$ SMOW and $S_{v}$ is the mean ocean salinity changes due to changes in the volume of the ice sheets (\%o) see equation (9) below.

$$
\mathrm{S}_{\mathrm{V}}=34.74 \times \mathrm{SL} /(3900-\mathrm{SL})
$$

where SL is the changes in sea level assuming a conversion of $0.012 \% / \mathrm{m}, 34.74$ is the present mean ocean salinity in \%o (GEOSECS, 1987), and 3900 is the present mean ocean depth in meters.

The source area within the Laurentide ice sheet which fed the increased iceberg flux during the Heinrich events is not known. If icebergs came from massive calving at the marine margins due to external climate forcing [Heinrich, 1988; Bond et al., 1992] the isotopic composition of the ice would be close to $-20 \%$ [Mix and Ruddiman, 1984]. An alternative theory is that the Laurentide ice sheet was part of a 'free oscillating system' [MacAyeal and Wang, 1992; MacAyeal, $1993 \mathrm{a \& b}$ ], and periodic melting of the soft, unconsolidated basal material occurred as a result of the temperature increase from geothermal heat, causing the ice sheet to 'fail' and to start surging on a massive scale [Andrews and Tedesco, 1992; MacAyeal and Wang, 1992; MacAyeal, 1993 a, b]. Ice dumped into the Labrador Sea via the Hudson Strait would have originated from both the centre and the margins of the ice sheet, thus its average isotopic composition would have been much lighter than $-20 \%$. Estimates of the average isotopic composition of the Laurentide icesheet have ranged from $-30 \%$ to $-40 \%$ [e.g., Shackleton, 1967b (-30\%o); Wely, 1968 (-40\%), Dansgaard and Tauber, 1969 (S -30\%o); Broecker, $1978(-35 \%)$ ]. Mix and Ruddiman (1984) stated that the present consensus on the mean isotopic composition of the Laurentide ice sheet during the LGM was $-35 \%$.

A second model was constructed to estimate the surface water salinity for the Heinrich events using the $-35 \%$ endmember.

$$
\mathrm{S}=\mathrm{S}_{\mathrm{m}}+\mathrm{S}_{\mathrm{v}}+1.120 \delta_{\mathrm{w}}^{*}
$$

The error of the salinity estimate was calculated, combining the assumed errors of the SST estimates (one standard deviation is $\pm 1^{\circ} \mathrm{C}$ (Pflaumann et al., submitted manuscript, 1995) and the oxygen isotope measurements (one standard deviation is $\pm 0.1 \%$ ( $M$. Hall, personal communication, 1993). The standard deviation in the salinity estimate is at least $\pm 0.65 \%$.

\section{Salinity Estimate Sensitivity to SST}

To investigate the sensitivity of the salinity estimates to the SST estimates two different approaches were used:

1. We first used the Duplessy et al. [1991, 1992] calibration method in conjunction with our own method (described above) to calculate summer surface water $\delta_{\mathrm{w}}$. We calculated the $\delta_{w}$ with two different SST estimates: the CLIMAP transfer function equation FA20 and SIMMAX EPOCH MAT (Figure 5). During the LGM the $\delta^{18} 0$ offset between the two estimates is up to $0.5 \%$, a difference of between $0.6-0.9 \%$ in surface water salinity, depending on whether equation (9) or (10) is used. This has implications concerning compatibility of salinity estimates made with different SST estimates. We used the CLIMAP FA20 estimate in this paper so that the results would be compatible with previous salinity estimates of Duplessy et al. [1991, 1992].

2. We also attempted to calculate summer and winter SSS by using the oxygen isotopic records of $G$. bulloides and $N$. pachyderma (s) separately (Figure 6). It has been shown that peak fluxes of $G$. bulloides in the North Atlantic are associated with phytoplankton blooms in the summer months [Ganssen, 1983]. During glacial period these phytoplankton blooms were restricted to a much shorter seasonal occurrence [Thomas et al., this issue]; thus during the last glacial $G$. bulloides may have only occurred during "high" summer [Ottens, 1991, 1992; Tolderlund and Bé, 1971; Ganssen and Sarnthein, 1983]. On the basis of these facts the alternative "summer" salinity calculation of the BOFS cores used the $G$. bulloides isotopic record and the summer SST as an estimate of the ambient surface water temperature (T). N. pachyderma (s) 
A G. bulloides

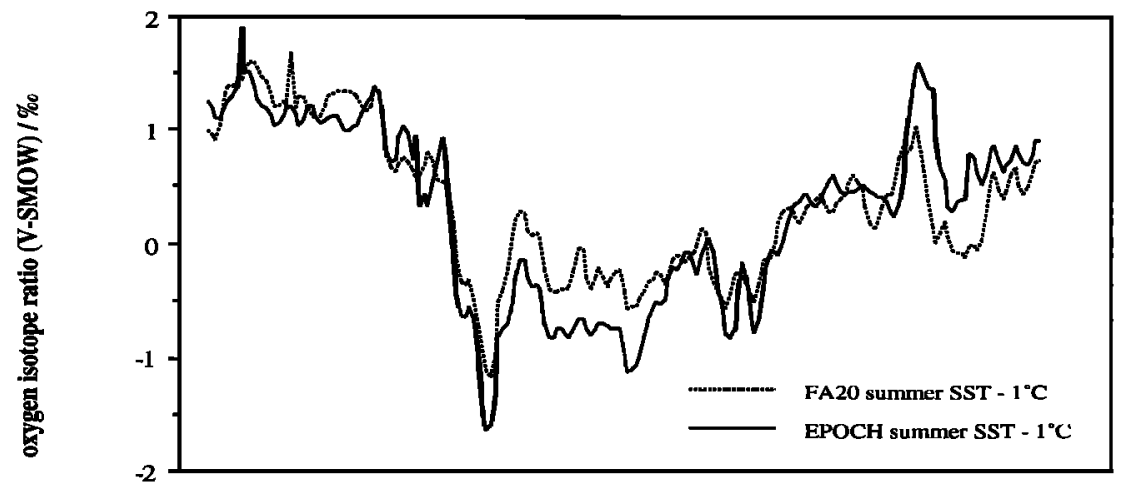

B/ N. pachyderma (L)

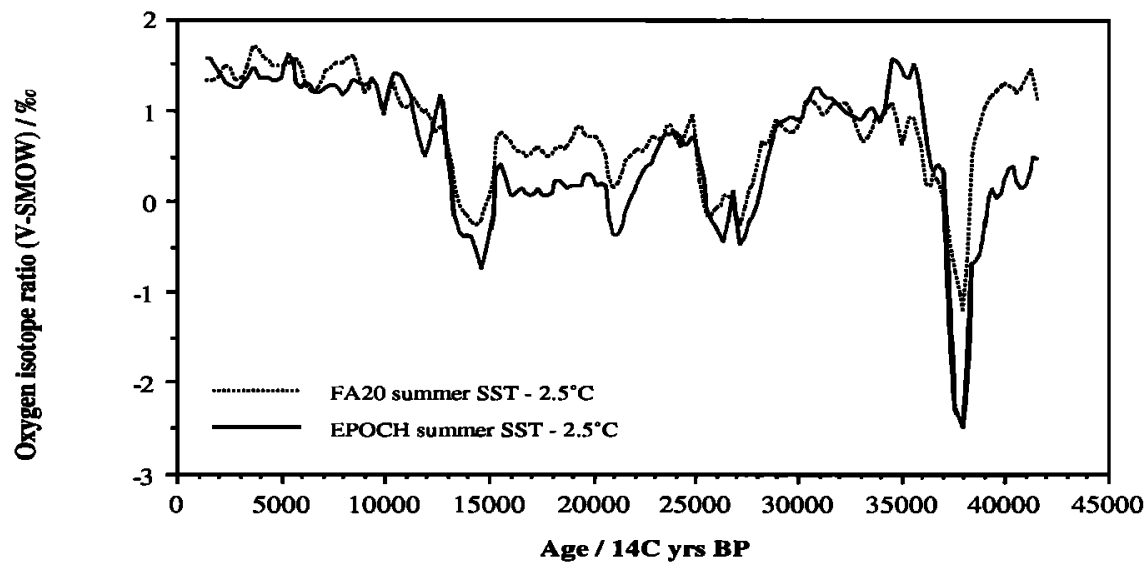

Figure 5. BOFS 5K: Comparison of the calculated surface water isotopic composition using two different SST estimates; CLIMAP FA20 and EPOCH (SIMMAX), for both the $G$. bulloides and $N$. pachyderma $(s)$ records. The SSTs were corrected according to the calibration of isotopic temperatures of Duplessy et al. [1991, 1992] see text.

present temperature range in the northeast Atlantic suggests that its annual occurrence may have been expanded during the last glacial to include some of the spring [Ottens, 1991\&1992; Tolderlund and Bé, 1971; Reynolds and Thunell, 1986]. For the alternative BOFS "winter" salinity calculation the $N$. pachyderma (s) oxygen isotope record and winter SST were used to estimate the ambiant surface water temperature (T). The records of $G$. bulloides and $N$. pachyderma (s) could thus provide a means of estimating the salinity during the late winter to early spring, and the summer.

Figure 6 shows these two alternative salinity calculations for summer and winter, compared with the variations in the global mean ocean salinity $\left(34.74 \%+S_{v}\right)$. During the last glacial the salinity of the northeast Atlantic surface waters was much lower than the global mean, presumably due to the large flux from melting icebergs. The Heinrich events are significant, especially in the $N$. pachyderma $(s)$ record, even assuming a meltwater input of $-35 \%$.

Calculated seasonal differences in the estimated salinity of BOFS 5K (summer minus winter salinity), shows that there were major shifts in the seasonality at each Heinrich event during the last 45,000 years (Figure 7). During Heinrich ice rafting events $2-4$, more meltwater was produced during the winter than during the summer. This could be correct only if the supply of icebergs to the northeast Atlantic during these periods varied on an annual basis. Dowdeswell and Murray [1990] have suggested that the maximum speed of floating iceberg is $0.5 \mathrm{~m} / \mathrm{s}$, therefore it would take a minimum of 100 days for an iceberg to cross from Newfoundland into the northeast Atlantic. Fillon [1985] has shown that the overall supply of icebergs to the North East Atlantic came from both the east and west of the Labrador Sea and east of Greenland. As icebergs follow the prevailing surface water currents, they would have had to travel up the east and then down the west of the Labrador Sea, and this would take at least another 100 days, while those icebergs produced on the east coast of Greenland would take even longer. Thus even if the production of icebergs were restricted to a particular season, the different time lags involved in the transportation of icebergs to the northeast Atlantic would mean that the seasonal "production" signal would have been obliterated (J. Dowdeswell, personal communications, 1992). The major control on the melting of the icebergs is surface water temperature [Dowdeswell and Murray, 1990], and thus the lowest salinities should be in the summer. This is opposite to what is shown by the seasonality of the salinity results of BOFS 5K and 8K at the LGM and H2-4 where the lowest-salinity estimates are found in the winter record. This suggests that the $G$. bulloides "summer" and $N$. pachyderma (s) "winter" definitions may be incorrect.

There are three possible expalanations for the anomalous 

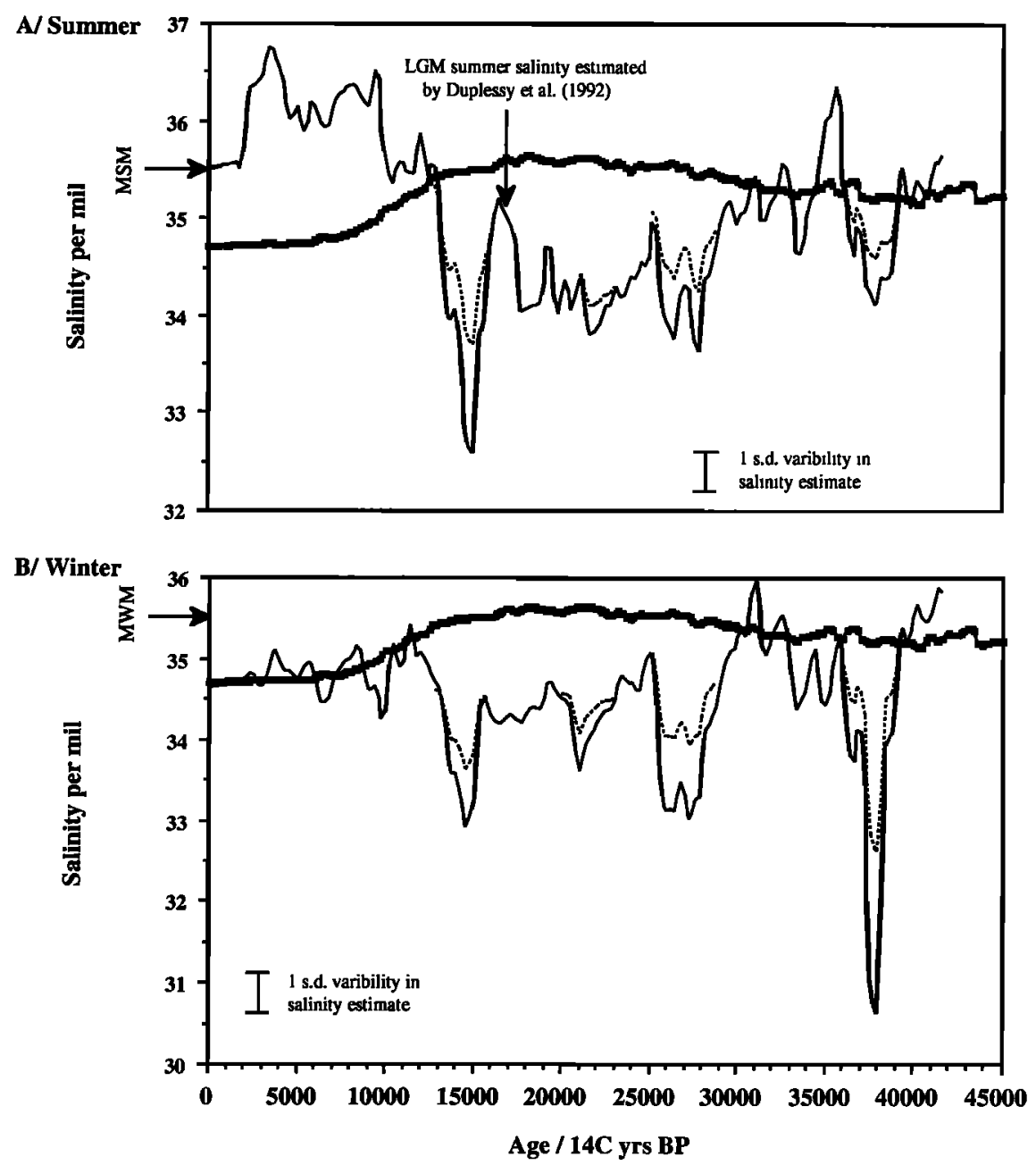

Figure 6. BOFS 5K: Solid line represent the sea surface salinity (SSS) calculated using equation 8 , assuming a meltwater input of $-20 \%$. Dotted lines represents the reconstruction of the SSS during the Heinrich events assuming a meltwater input of $-35 \%$ (equation 10). Solid squares represents the variation in the global mean ocean salinity. MWM, modern winter mean; MSM, modern summer mean salinity at $50^{\circ} \mathrm{N}$, $20^{\circ} \mathrm{W}$ [Ottens, 1991]. Error bar was calculated assuming an error of $\pm 1^{\circ} \mathrm{C}$ in the SST estimates and $\pm 0.1 \%$ in the oxygen isotope measurements.

results. First, the winter SST used for the $N$. pachyderma ( $s$ ) record may have been a significant under-estimate, suggesting that $N$. pachyderma ( $s$ ) occurred through out the year during the last glacial. The underestimate would have had to have been up to $4^{\circ} \mathrm{C}$, i.e., the difference between the summer and winter estimated SST. This is not large enough to explain the discrepancy at H4. Second, the $G$. bulloides abundances were very low (0-1\%) during the Heinrich events (see Figure 7), and the $G$. bulloides in the samples may only represent a small proportion of the 150-300 years that each sample represents. The $G$. bulloides thus may record sets of years only when the conditions are closer to its optimum, i.e., with higher sea surface temperatures due to fewer icebergs. In contrast, the $N$. pachyderma $(s)$ record represents the whole period, since the species is unaffected by low temperatures or salinity [Spindler and Dieckmann, 1986; Dieckmann et al., 1991]. Or third, there may have been no $G$. bulloides present during the Heinrich events and those found in the sediment are from bioturbation [Manigehetti et al., this issue].
In conclusion, we believe at present that the best method for calculating SSS is using the method we have suggested, with the $T^{*}$ calibrations and temperature ranges of $G$. bulloides and $N$. pachyderma (s) estimated by Duplessy et al. [1991, 1992], but there are, however, still many problems with the reliable calculation of sea surface salinity:

1. The reliance on the accuracy of the SST estimates: an error of $1^{\circ} \mathrm{C}$ alters the $\delta_{\mathrm{w}}$ estimate by over $0.5 \%$ (a salinity error of between $0.6-0.9 \%$; Figure 5).

2. The sensitivity of the salinity estimate to temperature means that the assumed temperature of calcification ( $T^{*}$ ) of each species is extremely important. In this study, two different assumptions were made about the seasonal, and thus SST occurrence of the foraminiferal species. Limitation of the combined summer salinity approach is that the assumption of $\mathrm{T}^{*}$ is based on the calibration of a core top data set including the whole North Atlantic. With such major changes in climate in the recent past it is unlikely that the $T^{*}$ has remained constant. 
A / Abundance of $G$. bulloides

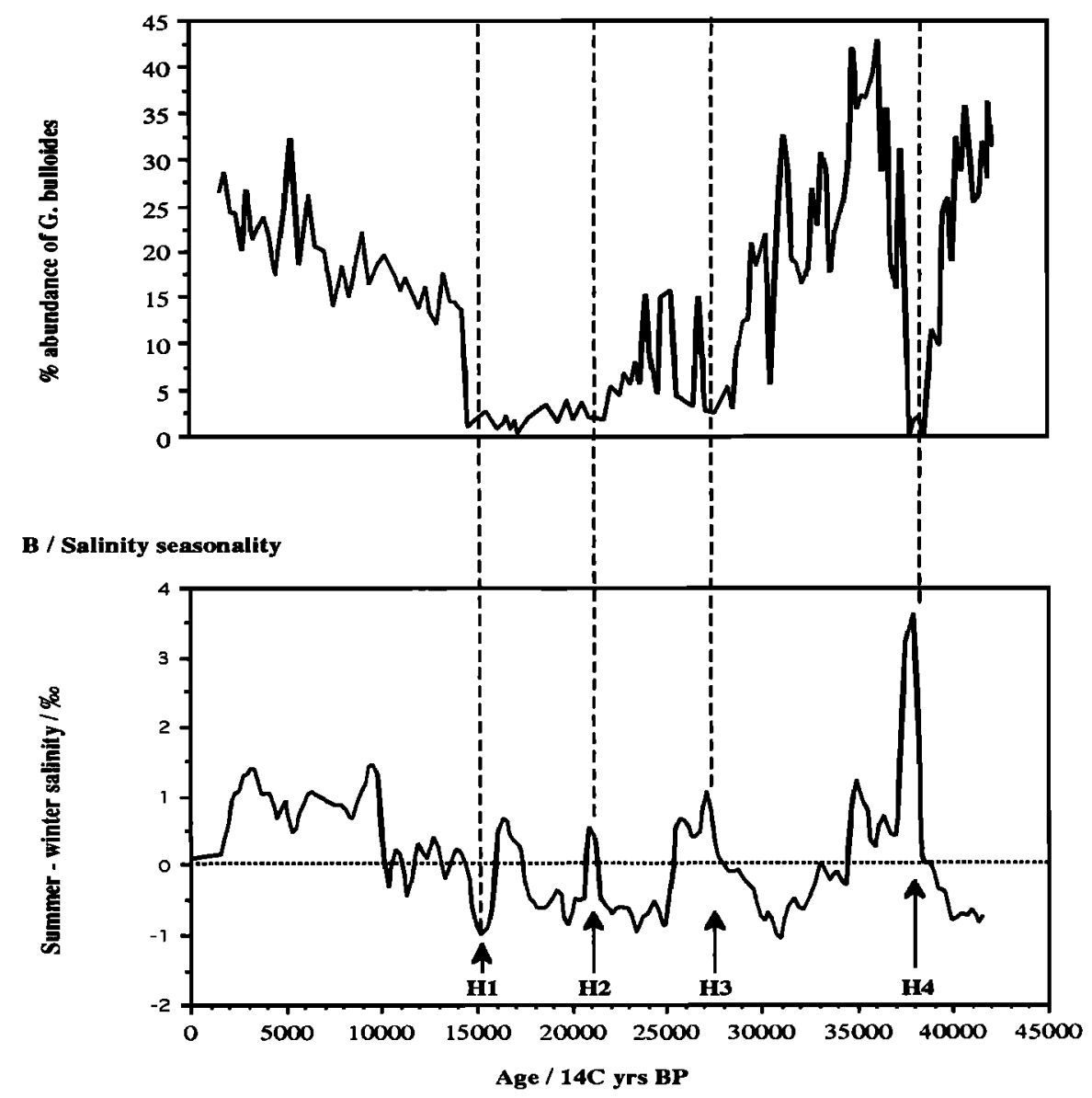

Figure 7. Comparison between (a) the relative percentage abundance of $G$. bulloides and (b) the reconstructed salinity seasonality in core BOFS $5 \mathrm{~K}$ for the last 45,000 years.

3. To calculate salinity, a $\delta_{\mathrm{w}}$ - salinity relationship must be assumed, and the salinity estimate is sensitive to the assumed isotopic composition of the meltwater input (Figures 6 and 7). This relationship is unlikely to be constant with time, as the evaporation-precepitation regime will have varied, and the source of the icebergs and thus their isotopic composition may not have been constant.

\section{Sea Surface Density}

Using the summer SST and SSS (Figure 8) it is possible to calculate the summer sea surface density, using the equation calibrated by Cox et al. [1970]. For comparison, we also calculated the density of NADW for the last 45,000 years by making assumptions about its temperature and salinity. The first assumption was the base salinity from which the global mean salinity variations due to ice volume $\left(S_{\mathrm{V}}\right)$ occurred. Labeyrie et al. [1992] suggested two different models, (1) assuming that the $S_{\mathrm{V}}$ changes occurred from the modern mean ocean salinity of $34.74 \%$ [GEOSECS, 1987], and (2) assuming that the $S_{\mathrm{V}}$ changes occurred from the salinity of NADW at the present, $34.95 \%$ [GEOSECS, 1987]. To calculate the density of NADW, temperature is required. Two temperatures were used, $1^{\circ} \mathrm{C}$ and $3^{\circ} \mathrm{C}: 3^{\circ} \mathrm{C}$ is the highest temperature recorded in NADW at present [GEOSECS, 1987], and $1^{\circ} \mathrm{C}$ is the lowest temperature of NADW during the last glacial according to benthic $\delta^{18} \mathrm{O}$ records [Labeyrie et al., 1992]. The most extreme estimates of NADW densities $\left(34.74 \%\right.$ at $3^{\circ} \mathrm{C}, 34.95 \%$ at $\left.1^{\circ} \mathrm{C}\right)$ are plotted on Figures 9 and 10 to compare with results from BOFS $5 \mathrm{~K}$ and $8 \mathrm{~K}$.

\section{Discussion of Summer Sea Surface Sallnity, Temperature and Density}

Figures 9 and 10 show the Heinrich events defined both by the WCMS and the $\%$ coarse fraction lithic debris of BOFS 5K and $8 \mathrm{~K}$, compared with the summer insolation at $60^{\circ} \mathrm{N}$ calculated by Berger and Loutre (1988): Heinrich events occurred at different insolation levels. H2 and H4 occurred while insolation was decreasing, $\mathrm{H} 3$ while the insolation was relatively stable and $\mathrm{H} 1$ when insolation increased, suggesting that the last four Heinrich events were not directly orbitally forced. This is in contrast to the suggestion of Bond et al. [1992], that the Heinrich events were due to repeated advances of the Laurentide icesheet after short 3000 year cooling episodes. There is no evidence in the BOFS cores for cooling periods before the Heinrich events, and clearly the major drop in SST occurred during the Heinrich events. 


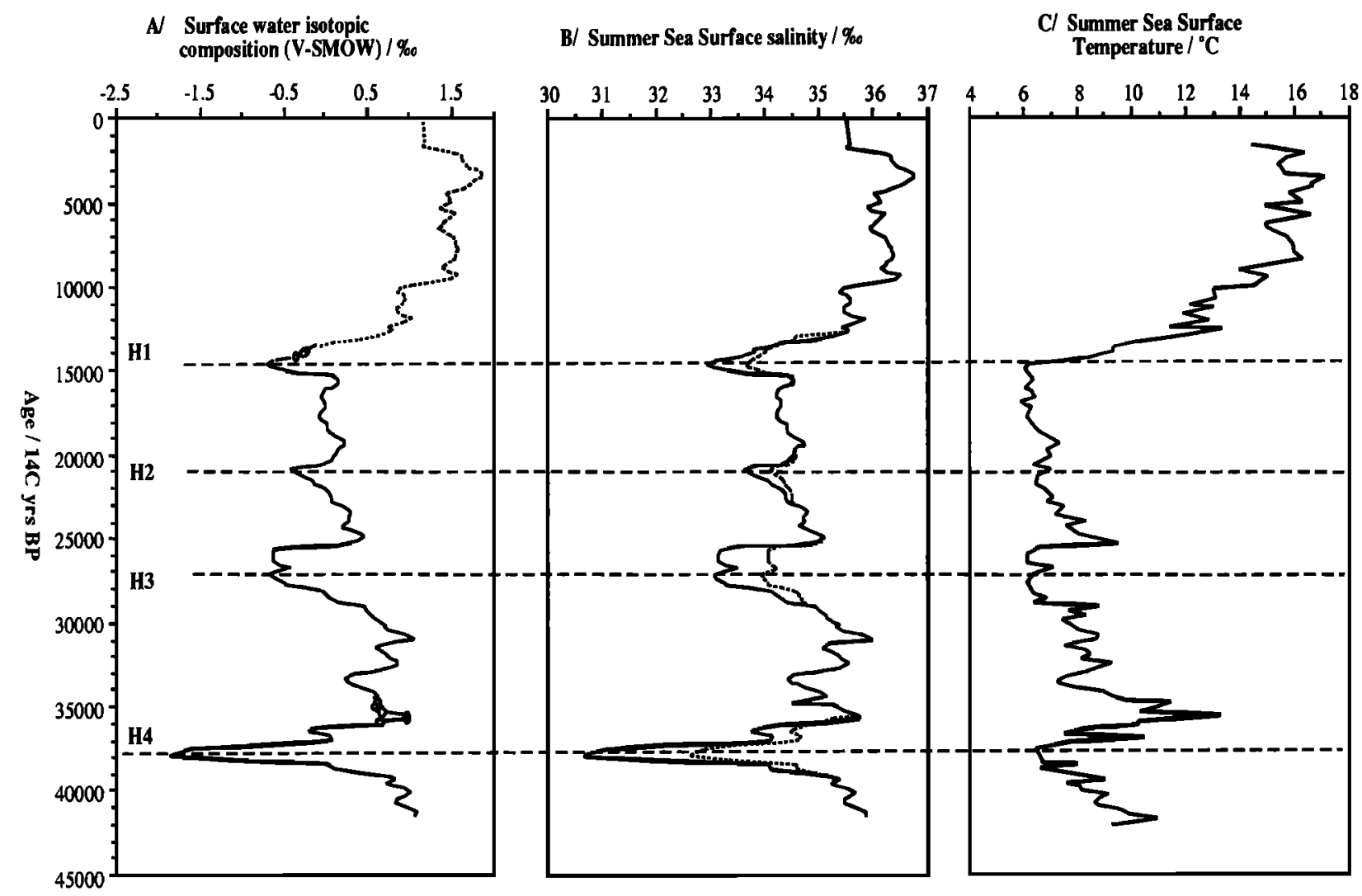

Figure 8. (a) BOFS 5K estimated surface water isotopic composition corrected for variations in global ice volume. Dotted lines represents $G$. bulloides results, solid $N$. pachyderma $(s)$ and open circles an average of the $G$. bulloides and $N$. pachyderma (s) results; defined by the isotopic temperature ranges of Duplessy et al. [1991, 1992], see text. (b) BOFS 5K: Summer sea surface salinity calculated from the composite record in Figure 8a. Solid line shows salinity calculated with a fresh water isotopic composition of $-20 \%$, dotted line shows salinity calculations for the Heinrich events assuming freshwater composition of $-35 \%$. (c) BOFS 5K: Summer sea surface temperatures estimated using the CLIMAP FA 20 equation.

Oerlemans [1993] modelled the possibilities of repeat advances of the Laurentide ice sheet as a cause of the Heinrich events, both with and without prior cooling episodes. He found that neither model could generate an appreciable increase in the calving rate during $\mathrm{H} 2$ or $\mathrm{H} 3$, and only a small increase during $\mathrm{H} 1$ which would not be sufficient to sustain the magnitude of the event observed in deep-sea sediments.

These results add support to the free-oscillating system theory of MacAyeal and Wang [1992] and MacAyeal [1993 a,b], who suggest that periodic melting of the soft unconsolidated basal sediment of the Laurentide ice sheet due to the build up of geothermal heat caused the ice sheet to fail and surge on a massive scale. Once enough ice had been calved out into the North Atlantic the blanket effect of the ice was removed and the sediment re-froze, halting the outpouring of ice. MacAyeal [1993 a,b] calculated that this free-oscillating system would cause the Laurentide ice sheet to fail every 7000 to 10,000 years, in agreement with the deep-sea sediment record.

During each of the Heinrich events there was a significant ( 1 to $4 \%$ ) drop in the SSS, presumably due to the input of fresh water from melting icebergs. During H2-4 SSTs were also lower, due to the input of near-freezing surface water. Despite the lower SST the surface water density dropped dramatically during Heinrich events. Our records show that the temperature drop occurred during and not before the Heinrich events. This is clearly shown in the extremely sharp boundaries at the base of the Heinrich events shown in the WCMS and Lithic content. X ray photographs of the BOFS cores also show this very sharp basal boundary and beneath the coarse ice-rafting material a "trichichnus layer" (a layer where microburrows are preserved, [Manighetti et al., this issue]). The presents of these burrows suggests that the initialisation of the Heinrich events occurred very rapidly on the order of years, thus adding support to the catastrophic failure theory.

At present, warm saline surface waters flow northward in the northeast Atlantic, and during this flow cooling increases their density. At a critical temperature, the surface water sinks, forming 'new' deep water in the Norwegian Sea. Robinson et al. [1995] from magnetic susceptibility of over 80 cores in the North Atlantic reconstructed the surface water circulation of the North Atlantic. Their results show that during the last glacial there was still northward transportation of surface water in the northeast Atlantic. The possibility 


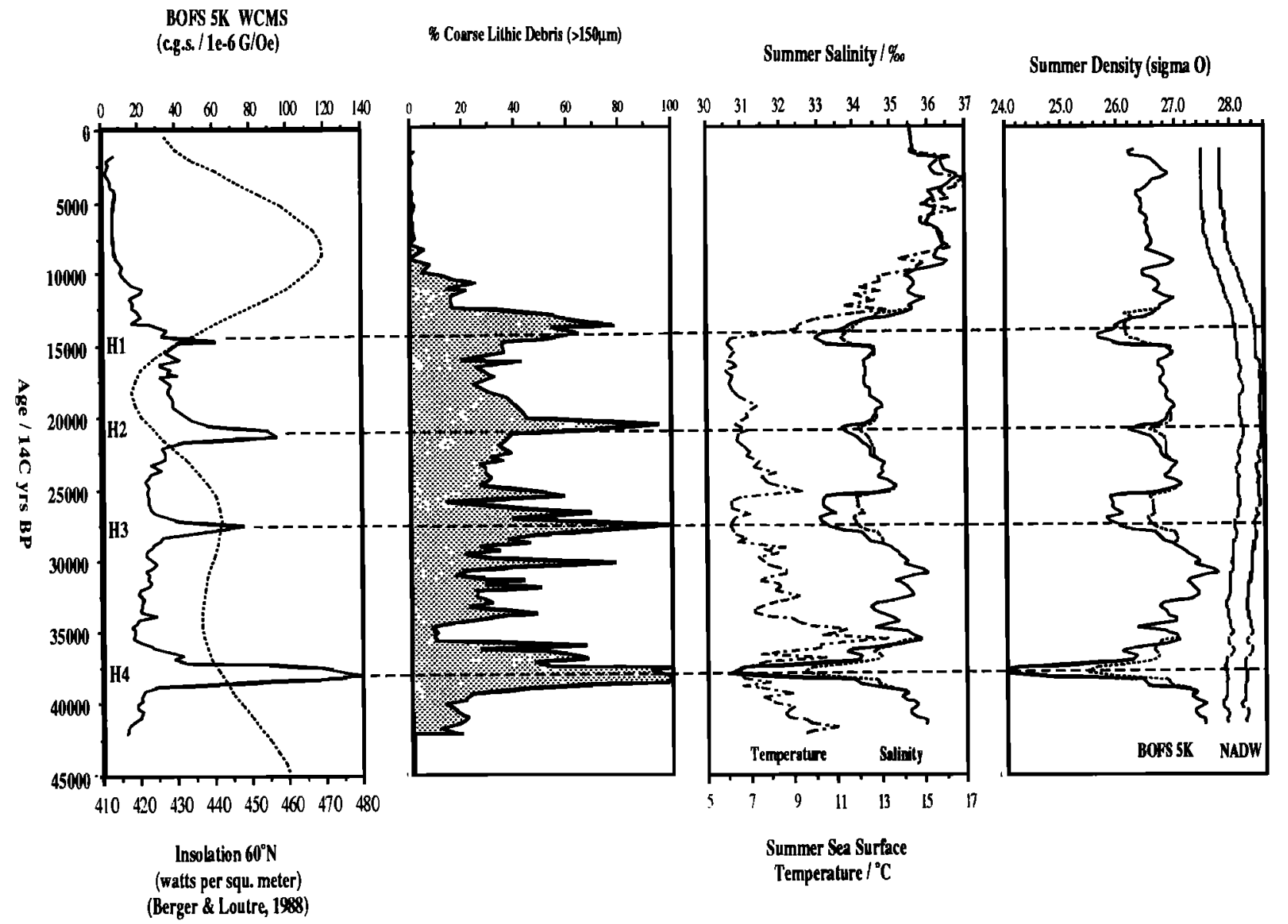

Figure 9. BOFS 5K: WCMS, percent coarse fraction lithic debris, summer sea surface temperature, salinity and density, compared with the insolation at $60^{\circ} \mathrm{N}$ [Berger and Loutre, 1988] and the calculated NADW density (see text).

that surface water which passed the site of $5 \mathrm{~K}$ could become dense enough to form NADW further north, was modelled by assuming that this surface water cooled as it flowed northward. Two temperatures to which the surface water may have cooled were selected and the surface water densities re-calculated. The first was the average August SST in the Norwegian Sea $\left(6^{\circ} \mathrm{C}\right)$ where deepwater forms at the present day [CLIMAP Project Members, 1976, 1982]. This allows reconstruction of the likely cooling during the Holocene and the warmer periods in the last glacial. The second temperature selected was the most extreme August SST in the far northeast Atlantic during the LGM, - 1. C [CLIMAP Project Members, 1976, 1982], reconstructing maximum cooling during the last glacial.

Figure 11 shows the density record at $5 \mathrm{~K}$, the estimated range of the NADW densities, and the range of densities assuming that $5 \mathrm{~K}$ surface water flowed northward and cooled to between $6^{\circ} \mathrm{C}$ and $1^{\circ} \mathrm{C}$. This does not take into account any variations in the salinity due to meltwater input or changes in the evaporation/precipitation regime, as there are no detailed down core salinity records for the far north North Atlantic. Duplessy et al. [1991], however, suggested that during the LGM the summer salinity in the far northeast Atlantic and Norwegian Sea was less than $1 \%$ lower than that at $50^{\circ} \mathrm{N}$. The salinity drop would have opposed the cooling effect by reduced the density and would have made deepwater formation even less likely.

Our model suggests that there may have been deepwater formation during the following periods: $41{ }^{14} \mathrm{C}$ ka to $39{ }^{14} \mathrm{C}$ $\mathrm{ka}$, which was halted by $\mathrm{H} 4,35{ }^{14} \mathrm{C}$ ka to $30{ }^{14} \mathrm{C}$ ka which was halted by $\mathrm{H} 3$, and present levels of deep water formation during the Holocene. This model agrees with the work of Labeyrie et al. [1992] who suggested that NADW was significantly reduced during much of the last glacial, from the salinity calculations of Duplessy et al. [1991]. They also suggested that NADW was fed only by small amounts of salty subtropical waters penetrating into the central northern Atlantic. Deepwater formation that could have occurred during the beginning of the last glacial was halted by Heinrich events H3 and H4. Broecker and Bond [1992] and Broecker [1994] have suggested that the reduction in the NADW during the Heinrich events may have pushed the climate system towards maximum glaciation. We agree but suggest that the climate response was more complicated; after each Heinrich event the climate overcompensated and there was a strong rise in both SST $\left(1^{\circ}\right.$ to $\left.6^{\circ} \mathrm{C}\right)$ and SSS ( 1 to $4 \%$ ). Only after a maximum of 2000 years did these milder episodes cease. We suggest that 


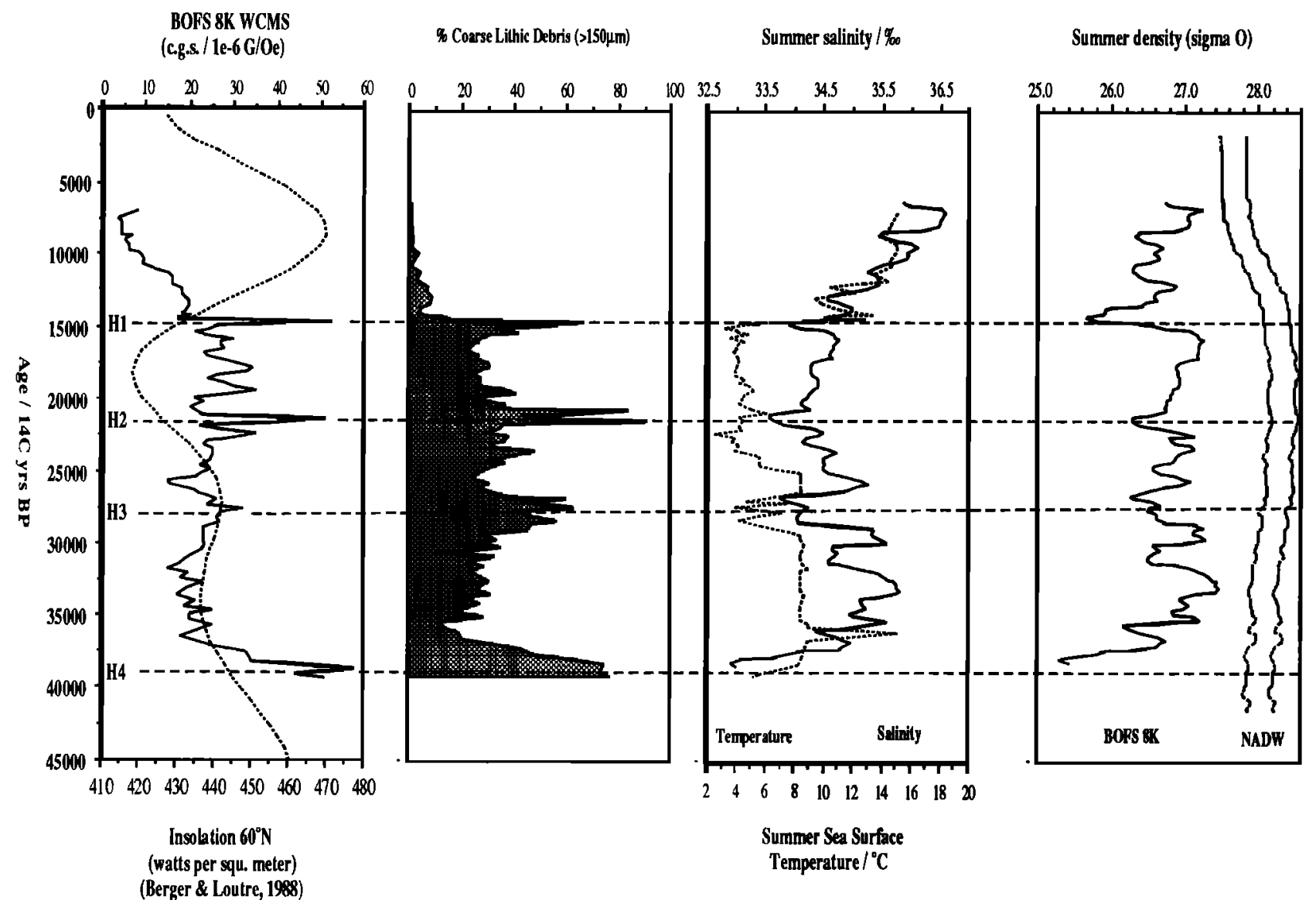

Figure 10. BOFS 8K: WCMS, percent coarse fraction lithic debris, summer sea surface temperature, salinity and density, compared with the Insolation at $60^{\circ} \mathrm{N}$ [Berger and Loutre, 1988] and the calculated NADW density (see text).

with the collapse of the Laurentide icesheet the predominant cold winds from the North American continent abated (D. Seidov et al., Towards a better understanding of the meltwater event near $13.6 \mathrm{kyr}$ B.P.: A numerical modelling approach, submitted to Paleoceanography 1995); thus reducing both the cooling of and the strength of the polar gyre, so allowing warmer southern water to penetrate further into the northeast Atlantic. Figure 12 shows our theoretical interpretation of the changes in the climate system over the last 45,000 years, including the climatic rebounds caused by the Heinrich events. This short-term cyclicity has also been shown convincently in the Greenland ice core and the North Atlantic sediment record from Ocean Drilling Program (ODP) Site 609 [Bond et al., 1993].

Of the first four Heinrich zones, $\mathrm{H} 1$ (14.8 - $13 \mathrm{kyrs})$ is unique as it occurs after the LGM, as both insolation and SST increased. Salinity estimates show that the iceberg meltwater effect during $\mathrm{H} 1$ was more wide spread than during the other Heinrich events, spanning at least $23^{\circ}$ latitude in the northeast Atlantic [Duplessy et al., 1992; Maslin, 1993; Keigwin and Lehman, 1994] as well as affecting the northwest Atlantic [Keigwin and Lehman, 1994]. H1 was coeval with the melting of the Fennoscandian ice sheet margins, which has been AMS ${ }^{14} \mathrm{C}$ dated as occurring between 15,000 and 13,000 years B.P.
[Weinelt et al., 1991; Sarnthein et al., 1992; Lehman and Keigwin, 1992]. This initial melting of the northern hemisphere ice sheets occurred as the summer insolation initially rose, suggesting that at least a part of this melting phase was climatically driven. This melting began at least $1500{ }^{14} \mathrm{C}$ years before the first major meltwater discharge from the Laurentide ice sheet [Fairbanks, 1989]. Though the inertia of ice sheet dynamics may have contributed to this delay it is unlikely that it is the whole cause. We suggest that the massive meltwater effect of ice rafting during $\mathrm{H} 1$ was able to reduce NADW and the heat exchange between the low and high latitudes, delaying the disintegration of the continental ice sheets by 1500 years after the initial melting of their margins.

Benthic foraminifera $\delta^{13} \mathrm{C}$ records from AMS ${ }^{14} \mathrm{C}$ dated cores from both the North and South Atlantic [Jansen and Veum, 1990; Charles and Fairbanks, 1992; Keigwin and Lehman, 1994] suggested that there was indeed reduced NADW between 14.6 and $13 \mathrm{kyr}$. From time slice reconstructions using over $95 \mathrm{AMS}{ }^{14} \mathrm{C}$ dated benthic $\delta^{13} \mathrm{C}$ records in the northeast Atlantic, Sarnthein et al. [1994]. have confirmed that the ventilation of the NADW was at its lowest for the whole of the last glacial between 14.6 and $13 \mathrm{kyr}$. This drop in benthic $\delta^{13} \mathrm{C}$ at $14.6 \mathrm{kyr}$ is coeval with the lowest SSD of 

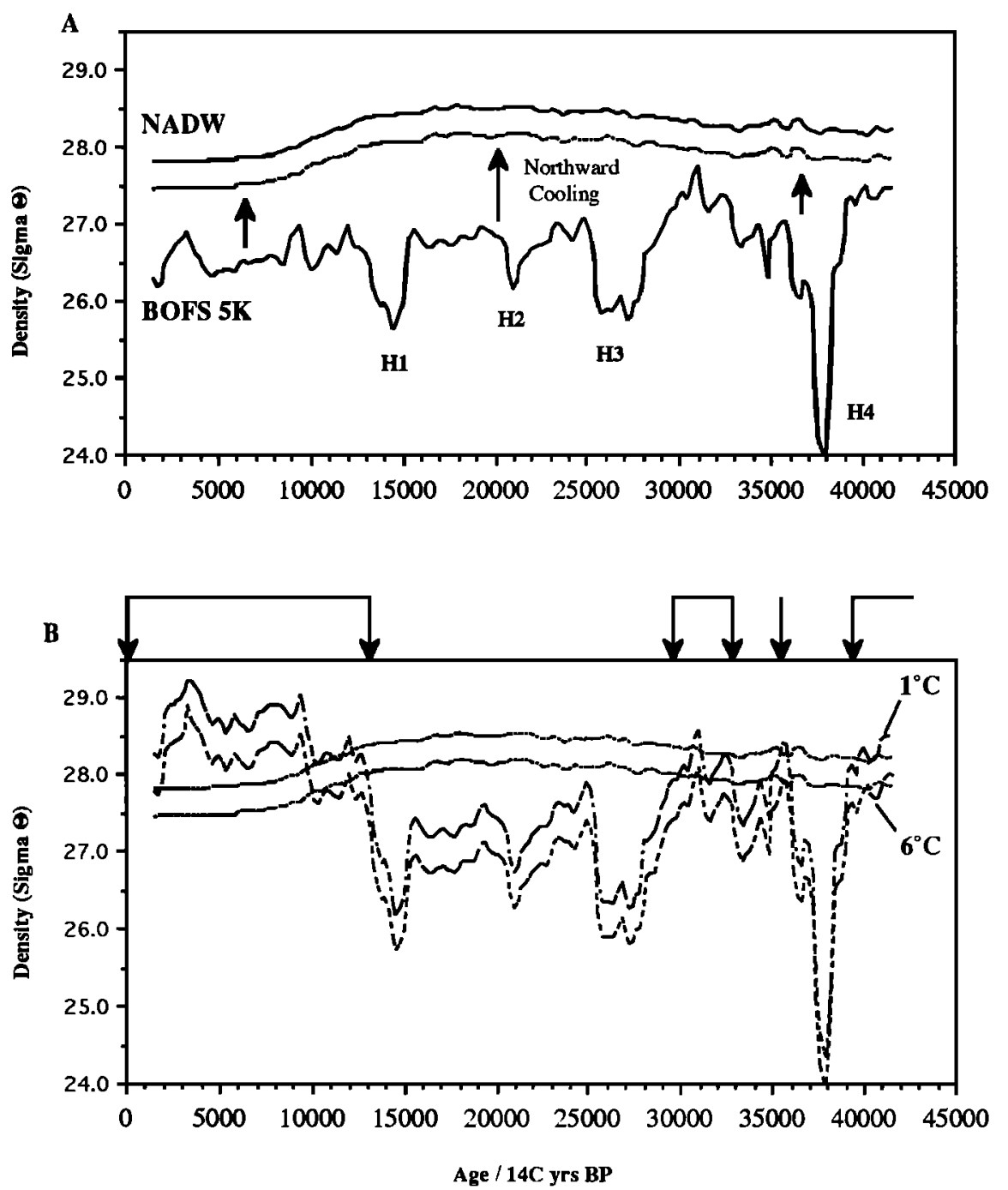

Figure 11. (a) The possible range of densities of the NADW (see text) compared with surface water densities at BOFS 5K for the last 45,000 years. (b) Modelled densities assuming northward transport of surface water from $5 \mathrm{~K}$ and cooling to either $6^{\circ} \mathrm{C}$ or $1^{\circ} \mathrm{C}$. Arrows indicate when there could have been deepwater formation in the far northeast Atlantic.

BOFS 5K and other published cores [Duplessy et al., 1992; Keigwin and Lehman, 1994, Figure 13]. This reduction in NADW production is also confirmed by the high benthic foraminifera Cd/Ca results at $\sim 14.5 \mathrm{kyr}$, from the Bermuda Rise [Keigwin et al., 1991]. When the meltwater effect at BOFS 5K ceased at $13 \mathrm{kyr}$ there is a dramatic rise in the benthic $\delta^{13} \mathrm{C}$, which Sarnthein et al. [1994] interpreted as a rapid switching "on" of the NADW. At $13 \mathrm{kyr}$ the discharge of the Laurentide ice sheet also rose sharply, and this marks the beginning of the first major retreat of the ice sheet [Fairbanks, 1989]. We suggest that with the switching 'on' of the NADW increased the transfer of heat from the lower latitudes, accelerating the disintegration of the northern hemisphere ice sheets.

We propose that the meltwater input from the increased flux of melting icebergs during $\mathrm{H} 1$ reduced deepwater formation, reducing the heat exchange between the high and low latitudes and was thus instrumental in delaying deglaciation by up to $1500{ }^{14} \mathrm{C}$ years (2000 calendar year).

\section{Conclusions}

During the last 45,000 years the characteristics of the surface water of the northeast Atlantic have been controlled by the relative influences of the polar and subtropical gyres. During the last glacial the northeast Atlantic was periodically affected by an enhanced flux of icebergs from the Laurentide icesheet, during the so called "Heinrich events". We present a new method of calculating SSS from the SST and $\delta^{18} O$ records of planktonic foraminifera. Our results show that there was a significant drop in the SST, SSS, and SSD during the Heinrich events, probably due to the input of meltwater.

Apart from the Heinrich events there was very little change in SSD between the glacial and Holocene in the northeast 
Warmer \&

Higher salinity

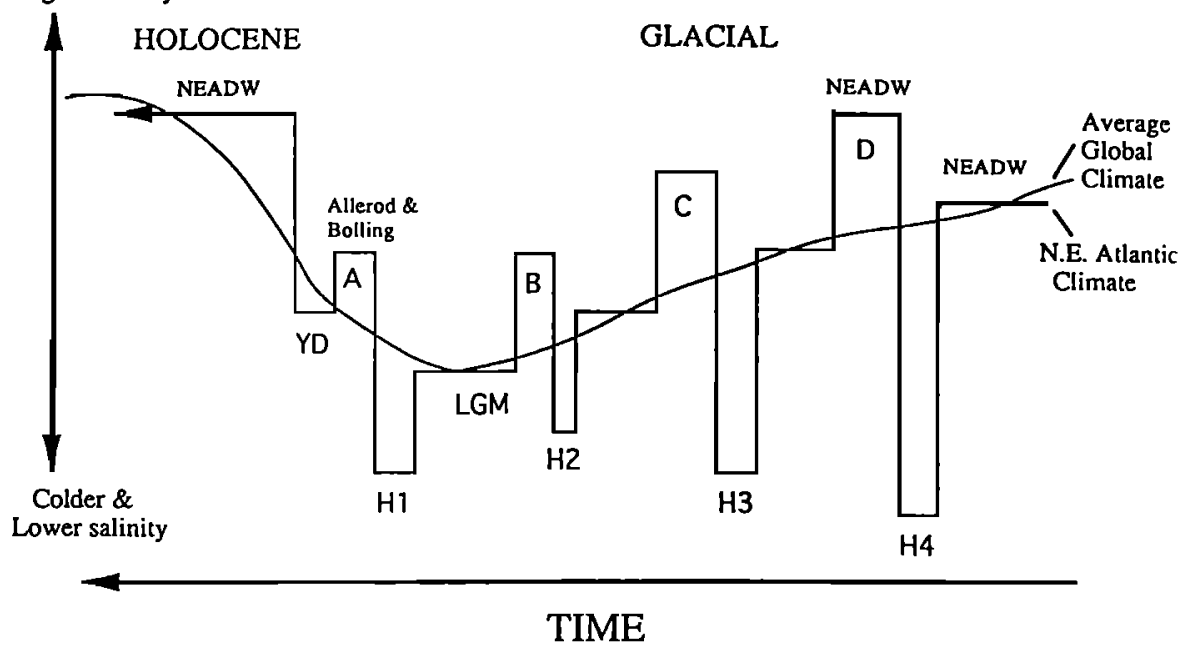

Figure 12. Theoretical reconstruction of the climate of the northeast Atlantic compared with the global climate for the last 45,000 years. Heinrich (H) 1-4 represent periods when the Laurentide ice sheet is failing calving out huge quantities of icebergs into the North Atlantic causing very cold and low-salinity surface waters. Peaks A-D represent climatic rebounds after the Heinrich events with much warmer and higher salinity conditions which last a maximum of two thousand years. NEADW are periods where there was NADW formation the far northeast Atlantic.

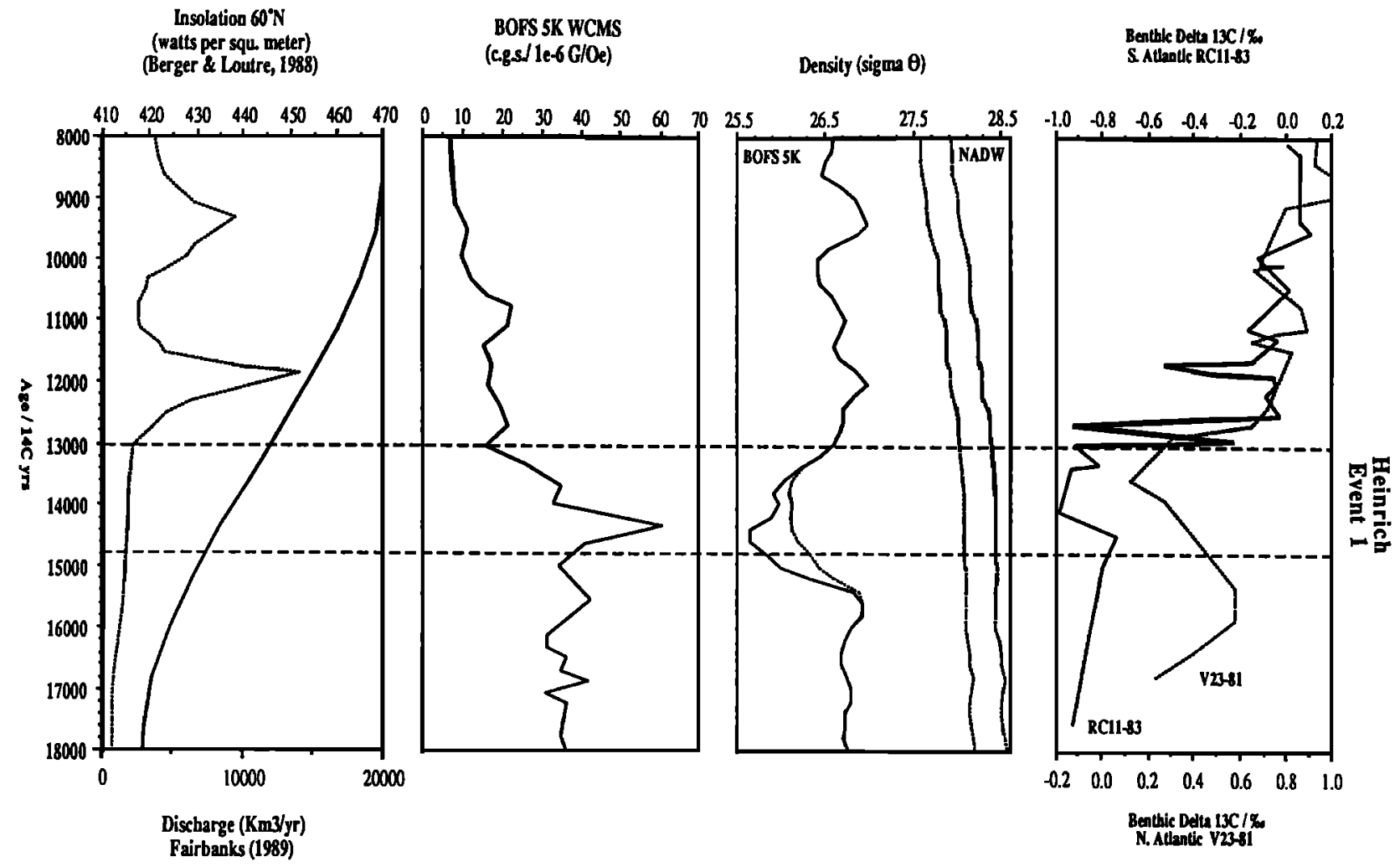

Figure 13. The insolation for $60^{\circ} \mathrm{N}$ [Berger and Loutre, 1988] and the Laurentide meltwater discharge [Fairbanks, 1989] are compared with the BOFS 5K whole core magnetic susceptibility and summer SSD records. BOFS 5K SSD shows a major drop between 15,000 and 13,200 years B.P. this is coeval with a decline in benthic $\delta^{13} \mathrm{C}$ records of V23-81 [Jansen and Veum, 1990] in the North Atlantic and RC11-83 [Charles and Fairbanks, 1992] in the South Atlantic indicating a reduced ventilation of the NADW between 14,600 and 13,000 . This reduced NADW ventilation may have been responsible for the 1500 years delay between the first initial melting of the northem hemisphere ice sheets during Heinrich event 1 and the first deglaciation step indicated by the Laurentide discharge curve. 
Atlantic because the increased local meltwater input during the last glacial countered the global rise in seawater salinity due to the growth of the ice sheets. Modelling cooling caused by the northward transportation of surface water in the northeast Atlantic, indicates that NADW formation could have occurred during the Holocene and at periods between 45,000 and 30,000 years. Deepwater formation was halted by $\mathrm{H} 3$ and $\mathrm{H} 4$, and no deepwater formation occurred between 30,000 and 13,000 years in the northeast Atlantic. We suggest that there is no evidence for cooling prior to the Heinrich events. We do observe climatic rebounds after each Heinrich event consisting of milder climate (with strong rises in both sea surface temperature and salinity) lasting a maximum of 2000 years, after which conditions returned to more average glacial levels. These cold and warm episodes in the northeast Atlantic are superimposed on the general trend during the last glacial towards colder condition of the LGM and the rapid deglaciation. We suggest that the Heinrich events and their associated reduction in NADW production were instrumental in enhancing glacial conditions. The exception to this is $\mathrm{H} 1$ which occurred while insolation rose. The reduction in deepwater formation during this period because of the great meltwater input from the inceased iceberg flux may have caused deglaciation to be delayed by $1500{ }^{14} \mathrm{C}$ years $(2000$ calendar years).

Further work is required to investigate the links between the Heinrich events, deep water formation and global climate. If this is confirmed then we must consider that the Heinrich events (and their assocaited warm periods) may have been part of a non-Milankovitch free-oscillating system, externally forced only by the presence or absence of an icesheet on the North American continent.

Acknowledgments. We would like to thank the following: Ellen Thomas, Mike Hall, Simon Crowhurst, J. Le, Julian Dowdeswell, Andrew Richards, Neil Loader, Linda Booth, Jenni Token, Lorraine Crump, Andrew Gerrand, J-C. Duplessy and M. Arnold (for measuring the AMS ${ }^{14} \mathrm{C}$ dates on BOFS 5K), Hartmut Schultz, Michael Sarnthein, Scot Lehman, Simon Robinson, Nick McCave, and the review by L. Labeyrie which greatly improved the manucript. We would also like to thank NERC and the European Community (EPOCH) for the support during this work.

\section{References}

Andrews, J.T., and K. Tedesco, Detrital carbonate rich sediments, northwestern Labrador Sea: Implications for ice sheet dynamics and iceberg rafting (Heinrich) events in the North Atlantic. Geology, 20 1087-1090, 1992.

Bard, E., R. Fairbanks, M. Arnold, P. Maurice, J. Duprat, J. Moyes, and J-C. Duplessy. Sea level estimates during the last deglaciation based on $\delta^{18} \mathrm{O}$ and accelerator mass spectrometry ${ }^{14} \mathrm{C}$ ages measured on Globigerina bulloides, Quat. Res., 31, 381-391, 1989.

Bard, E., B. Hamelin, R. Fairbanks, and A. Zindler, Calibration of the ${ }^{14} \mathrm{C}$ timescale over the past 30,000 years using mass spectrometric U-Th ages from Barbados corals, Nature, 345, 405-409, $1990 \mathrm{a}$.

Bard, E., B. Hamelin, and R. Fairbanks, U-Th age obtained by mass spectrometry in corals from Barbodos: sea level during the past 130,000 years, Nature, 346, 456-458, $1990 \mathrm{~b}$.
Bé, A.W.H, An ecological, zoogeographical, and taxonomic review of recent planktonic foraminifera, in Oceanic Micropaleontology, vol 1, edited by A.T.S. Ramsay, pp. 1-100, 1977.

Berger, A., and M.F. Loutre, New insolation values for the climate of the last 10 million years. Sci. Rep. 1988/13 Inst. d'Astron. et de Geophys. Georges Lemaitre, Univ. Catholique de Louvain-la-Neuve, Belgium,1988.

Birks, H.J.B., J. Line, S. Juggins, A. Stevenson, C. Braak, and J. Ter. Diatoms and $\mathrm{pH}$ reconstruction, Philos. Trans. $R$. Soc. London B, 327, 262-278, 1990.

Bond, G., et al., Evidence for massive discharges of icebergs into the North Atlantic ocean during the last glacial, Nature, 360, 245-249, 1992.

Bond, G., W. Broecker, S. Johnsen, J. McManus, L. Labeyrie, J. Jouzel and G. Bonani, Correlation between climate records from North Atlantic sediments and Greenland ice, Nature, 365, 143-147, 1993.

Broecker, W., The causes of glacial to interglacial climatic change, in Handbook of Environmental Isotopic Geochemistry, vol. 1, The Terrestrial Environment., edited by P. Fritz pp. 473-504, Elsevier, New York, 1978.

Broecker, W., Massive iceberg discharges as triggers for global climate chnageNature, 372, 421-424, 1994.

Broecker, W., M. Andree, W. Wolfli, H. Oeschger, G. Bonani, J. Kennett, and D. Peteet, The chronology of the last deglaciation: Implications to the cause of the Younger Dryas, Paleoceanography, 3 , 1-19, 1988.

Broecker, W.S., and G. Bond, What are the Heinrich events trying to tell us?, in IPC $I V, \mathrm{p} 72$, University of Kiel, Kiel, Germany, 1992.

Broecker, W.S., and G. Denton, The role of atmospheric reorganisation in glacial cycles, Geochim. Cosmochim. Acta, 53, 2465-2501, 1988.

Broecker, W.S., G. Bond, M. Klas, G. Bonani, and W. Wolfli, A salt oscillator in the glacial Atlantic?, 1, The concept, Paleoceanography, S, 469-478, 1990.

Broecker, W., G. Bond, M. Klas, E. Clark, and J. McManus, Origin of the northern Atlantic's Heinrich events, Climate Dynamics, 6, 265-273, 1992.

Charles, C., and R. Fairbanks, Evidence from Southern Ocean sediments for the effects of North Atlantic deep-water flux on climate, Nature, 355, 416-419, 1992.

Climate: Long-Range Investigation, Mapping and Prediction (CLIMAP) Project Members, The surface of the ice-age earth, Science, 191, 1131-1137, 1976.

Climate: Long-Range Investigation, Mapping and Prediction (CLIMAP) Project Members, Seasonal reconstructions of the earth's surface at the glacial maximum, Map and Chart Ser. MC.36 pp. 1-18, Geol. Soc. of Am., Boulder, Colo., 1981.

Coope, G.R., Climate reconstruction, Philos. Trans. R. Soc. London B, 280, 313-348, 1977.

Coplen, T.B., C. Kendall, and J. Hopple, Comparison of stable isotope reference samples, Nature, 302, 236-238, 1983.

Cox, R., M. McCartney, and F. Culkin, The specific gravity / salinity / temperature relationships in natural sea water, Deep Sea Res. 17 , 679-689, 1970.

Craig, H., and L. Gordon, Deuterium and oxygen 18 variation in the ocean and the marine atmopshere, in Stable Isotopes in Oceanographic Studies and Paleotemperatures, edited by E. Tongiorgi pp. 9-130. Consiglio Nazionale delle Ricerche, Pisa, Italy, 1965.

Cullen J. L., Microfossil evidence for changing salinity patterns in the Bay of Bengal over the last 20,000 years, 
Palaeogeogr. Palaeoclimatol. Palaeoecol., 35, 315-356, 1981.

Dansgaard, W. and H. Tauber, Glacial oxygen-18 content and Pleistocene ocean temperatures, Science, 166, 499-502, 1969.

Dieckmann, G.S., M. Spindler, M.A. Lange, S.F. Ackley, and H. Eicken, Antartctic sea ice: a habitat for the foraminifera Neogloboquadrina pachyderma, J. Foraminiferal Res., 21 , 182-189, 1991.

Dowdeswell, J., and T. Murray, Modelling rates of sedimentation from icebergs." In Glacimarine Environments: Processes and Sediments, edited by J. Dowdeswell \& J. Scourse. Geol. Soc. Spec. Publ., London 53, 121-137, 1990.

Duplessy, J-C., L. Labeyrie, A. Juillet-Leclerc, F. Maitre, J. Duprat, M. Sarnthein, Surface salinity reconstruction of the North Atlantic Ocean during the last glacial maximum, Oceanol. Acta, 14 (4), 311-324, 1991.

Duplessy, J-C, L. Labeyrie, M. Arnold, M. Paterne, J. Duprat and T. van Weering, Changes in surface water salinity of the North Atlantic Ocean during the last deglaciation, Nature, 358, 485-488, 1992.

Fairbanks, R.G., A 17,000 year glacio-eustatic sea level record: Influence of glacial melting rates on the Younger Dryas event and deep-ocean circulation, Nature, 342, 637 642, 1987.

Fillon, R.H., Northwest Labrador Sea stratigraphy, sand input and Paleoceangraphy during the last 160,000 years, in Quaternary Environments: Eastern Canadian Arctic, Baffin Bay and Western Greenland, edited by J.T. Andrews pp. 211-247, Allen and Unwin, Winchester, Mass., 1985.

Fillon, R.H., G.H. Miller, and J.T. Andrew, Terrigenous sand in Labrador Sea hemipelagic sediments and paleoglacial events on Baffin Island over the last 100,000 years, Boreas, 10, 107-124, 1981.

Fillon, R.H., and D.F. Williams, Dynamics of meltwater discharge from Northern Hemisphere ice sheet during the last deglaciation, Nature, 310, 674-676, 1984.

Ganssen, G., Dokumentation von Köstennahem Auftrients anhand stabiler Isotope in rezenten Foraminiferen vor Nordwest-Afrika, Meteor Forsch-Ergeb., Reile 37, 1983.

Ganssen, G. and M. Sarnthein, Stable isotope composition of foraminifera: the surface and bottom waters record of coastal upwelling, in Coastal Upwelling, Its Sediment Record, Part $A$, edited by A.E. Suess and J. Thiede. Plenum, New York, 1983.

Geochemical Ocean sections Study (GEOSECS), Atlantic, Pacific and Indian Ocean expeditions: Shorebased Data and Graphics, vol. 7, edited by H. Craig H.G. Ostlund W.S. Broecker and D. Spencer. National Science Foundation, Washington D.C., USA, 1987.

Grousset, F.E., L. Labeyrie, J.A. Sinko, M. Cremer, G. Bond, J. Duprat, E. Cortijo, and S. Huon, Patterns of Ice-rafted detritus in the North Atlantic (40-55'N), Paleoceanography, 8, 175-192, 1993.

Heinrich, $\mathrm{H}$., Origin and consequences of cyclic ice rafting in the northeast Atalntic Ocean during the past 130,000 years, Quat. Res., 29, 142-152, 1988.

Hutson, W.H., The Agulhas current during the late Pleistocene: Analysis of modern analogues, Science, 207, 64-66, 1979.

Imbrie, J., and N.G. Kipp, A new micropalecntological method for quantitative paleoclimatology, in Late Cenozoic Glacial Ages, edited by K.K. Turekian, pp. 71-182. Yale University Press, New Haven, Conn., USA, 1971.

International Atomic Energy Agency, Statistical treatment of environmental data in precipitation, Technical Report Ser. 206, Vienna, 1981.
Jansen, E., and T. Veum, Evidence for two step deglaciation and its impact on North Atlantic deep water circulation, Nature, 343, 612-616, 1990.

Keigwin, L.D. and S. Lehman, Deep circulation changes linked to Heinrich event 1 and Younger Dryas in a mid-depth North Atlantic core, Paleoceanography, 9, 185-194, 1994.

Keigwin, L.D., G. A. Jones, and S. Lehman, Deglacial meltwater discharge, North Atlantic Deep water circulation and abrupt climate change, J. Geophys. Res., 96, 1681116826, 1991.

Kipp, N.G., New transfer function for estimating past sea surface conditions from sea-bead distributions of planktonic foraminifera assemblages in the north Atlantic, in Investigations of Late Quatemary Paleoceanography and Paleoclimatology, edited by R.M. Cline and J.D. Hays, Mem. Geol. Soc. Am., 145, 3-41, 1976.

Labeyrie, L.D., J-C. Duplessy, and P.L. Blanc, Variations in the mode of formation and temperature of oceanic deep waters over the past 125,000 years, Nature, 327, 477-482, 1987.

Labeyrie, L. D., J-C. Duplessy, J. Duprat, A. Juillet-Leclerc, J. Moyes, E. Michel, N. Kallel, and N. J. Shackleton, Changes in the vertical structure of the North Atlantic Ocean between Glacial and Modern times, Quat. Sci. Rev., 11 (4), 401-414, 1992.

Le, J., Temperature and carbonate dissolution variability in the western equatorial Pacific during the late Quaternary, Ph.D. thesis, Cambridge University, Cambridge, England 1991.

Le, J., Review of palaeotemperature estimates based on planktonic foraminifera: Application to two Western equatorial Pacific cores, Quat. Sci. Rev., in press, 1995.

Lehman, S.J., and L.D. Keigwin, Sudden changes in North Atlantic circulation during the last deglaciation, Nature, 356, 757-762, 1992.

Levitus, S. Climatological atlas of the worlds oceans, NOAA Prof. Pap. 13, 173pp., U.S. Govt. Print. Office, Washington, D.C., 1982.

MacAyeal, D.R., A low order model of the Heinrich events cycle, Paleoceanography, 8, 767-775, 1993 a.

MacAyeal, D.R., Binge/purge oscillations of the Laurentide ice sheet as a cause of the North Atlantic's Heinrich events, Paleoceanography, 8, 775-785, $1993 \mathrm{~b}$.

MacAyeal, D.R. and H-L. Wang, A glaciological throttle on fresh water input to the North Atlantic Ocean during glacial climates (abstract), Eos Trans., AGU 73 (43), Fall Meeting Suppl., 158,1992.

Manabe, S. and R. Stouffer, Two stable equilibria of a coupled ocean-atmosphere model, Int. J. Climatology, 1, 841-866, 1991.

Manighetti, B., M.A. Maslin, I.N. McCave, and N.J. Shackleton, Chronology for the Climate Change: Developing age models for the Biogeochemical Ocean Flux Study cores, Paleoceanography, this issue.

Maslin, M.A., A study of the palaeoceanography of the N.E. Atlantic in the late Pleistocene." Ph.D. thesis, Cambridge Univ., Cambridge, England, 1993.

McIntyre, A., N.G. Kipp, A.W.H. Bé, T. Crowley, T. Kellogg, J.V. Gardner, W. Prell, W.F. Ruddiman, Glacial North Atlantic 18,000 years ago: A CLIMAP reconstruction, in Investigations of Late Quaternary Paleoceanography and Paleoclimatology, edited by R.M. Cline and J.D. Hays, Mem. Geol. Soc. Am., 145, 43-76, 1976.

McIntyre, A., W.F. Ruddiman, K. Karlin, and A. Mix, Surface water response of the equatorial Atlantic Ocean to orbital forcing, Paleoceangraphy, 4, 19-55, 1989. 
Mix, A., and W.F. Ruddiman, Oxygen 1sotope analyses and Pleistocene Ice Volumes, Quat. Res., 21, 1-20, 1984.

Mix, A.C., W.F. Ruddiman, and A. McIntyre, Late Quaternary paleoceanography of the tropical Atlantic 1: Spatial variability of annual mean sea-surface temperatures, 0 20,000 B.P., Paleoceangraphy, 1, 42-66, 1986.

Molfino, B., N.G. Kipp, and J.J. Morley, Comparison of foraminiferal, Coccolithophorid, and Radiolarian paleotemperature equations: assemblage coherency and estimate concordancy, Quat. Res., 17, 279-313, 1982.

Oerlemans, J., Evaluating the role of climatic cooling in iceberg production and the Heinrich events, Nature, 364, 783-785, 1993.

O'Neil, J., R. Clayton, and T. Mayeda, Oxygen isotope fractionation in Divalent metal carbonates, J. Chem. Phys., 51 (12), 5547-5558, 1969.

Ostlund, H.G., H. Craig, W.S. Broecker and D. Spencer, GEOSECS, Atlantic, Pacific and Indian Ocean expeditions; Shorebased Data and Graphics, vol. 7. GEOSECS Atlas Series, National Science Foundation, Washington, D.C., USA, 1987.

Ottens, J., Planktonic forminifera as North Atlantic water mass indicators, Oceanol. Acta, 14, 123-140, 1991.

Ottens, J. "Plan. thesisktonic foraminifera as indicators of ocean environments in the northeast Atlantic, Ph.D thesis, Amsterdam University, Amsterdam, Holland, 1992.

Overpeck, J.T., T. Webb III, and I.C. Prentice, Quantitative interpretation of fossil pollen spectra: Dissimilarity coefficients and the method of modern analogues, $Q$ uat. Res. 23, 87-108, 1985.

Pflaumann, U., C. Pujol, M. Duprat, and L. Labeyrie. "SIMMAX, A transfer function technique to deduce Atlantic sea surface temperatures from planktonic foraminifera - The EPOCH approach, ICP IV, Kiel, Germany, 1992.

Prell, W.L., The stability of low-latitude sea-surface temperature: An evaluation of the CLIMAP Reconstruction with emphasis on the positive SST anomalies, Tech. Tep. TR025, Department of Energy, Washington, D.C., USA, 1985.

Reynolds, L.A., and R.C. Thunell, Seasonal production and morphological variation of Neogloboquadrina pachyderma (Ehrenberg) in the Northeast Pacific, Micropaleontology, 32, 1-18, 1986.

Robinson, S., M.A. Maslin, and I.N. McCave, Magnetic susceptibility variations in Late Pleistocene deep-sea sediments of the North East Atlantic: Implications for ice rafting and palaeocirculation at the Last Glacial Maximum, Paleoceanography, in press, 1995.

Ruddiman, W. F., Late Quatemary deposition of ice-rafted sand in the subpolar North Atlantic (lat $40^{\circ} \mathrm{N}$ to $65^{\circ} \mathrm{N}$ ), Geol. Soc. Am. Bull., 88, 1813-1827,1977.

Ruddiman, W.F., and A. Esmay, A steamlined foraminiferal transfer function for the subpolar North Atlantic, in Initial Rep. Deep Sea Drill., Proj. 94, 1045-1057, 1987.

Ruddiman, W.F., and A. McIntyre, Northeast Atlantic Paleoclimate change over the past 600,000 years, in Investigation of Late Quaternary Paleoceanography and Paleoclimatology, edited by R.M. Cline and J.D. Hays, Mem. Geol. Soc. Am. 145, 111-146, 1976.

Sarnthien, M., E. Jansen, M. Arnold, J-C. Duplessy, H. Erlenkeuser, A. Flatoy, T. Veum, E. Vogelsang, and M. Weinelt, $\delta^{18} \mathrm{O}$ time slice reconstruction of meltwater anomalies at Termination 1 in the North Atlantic between $50^{\circ}$ and $80^{\circ} \mathrm{N}$, in The Last Deglacial: Absolute and Radiocarbon Chronologies NATO ASI Series, vol 12., edited by E. Bard and W. Broecker, Springer-Verlag, Berlin, 1992.

Sarnthein, M., K. Winn, S. Jung, J-C. Duplessy, L. Labeyrie, H.Erlenkeuser, and G. Ganssen, Changes in East Atlantic Deepwater Circulation over the last 30,000 years - an eight time slice reconstruction, Paleoceanography, 9, 209-268, 1994.

Shackleton, N.J., The measurement of Palaeotemperatures in the Quaternary Era, Ph.D thesis, Univ. of Cambridge, Cambridge, England, 1967a.

Shackleton, N.J., Oxygen isotope anaysis and Pleistocene temperatures re-assessed, Nature, 215, 15-17, $1967 \mathrm{~b}$.

Shackleton, N. I., Attainment of isotopic equilibrium between ocean water and the benthic foraminifera genus Uvigerina: Isotopic changes in the ocean during the last glacial, report CNRS, Gif sur Yvette, Paris, 1974.

Shackleton, N.J., Oxygen isotopes, ice volume and sea-level, Quat. Sci. Rev., 6, 183-190, 1987.

Shackleton, N.J. and N. Pisias, Atmospheric carbon dioxide, orbital forcing and climate, in The Carbon Cycle and Atmospheric Carbon Dioxide: Natural Variation Archean to Present, Geophys. Monogr., vol. 32 , edited by E. T. Sunquist and W.S. Broecker, pp. 303-317, AGU, Washington, D.C., USA, 1985.

Shackleton, N.J., J-C. Duplessy, M. Arnold, P. Maurice, M. A. Hall, and J. Cartlidge, Radiocarbon age of the last glacial Pacific deep water, Nature, 335, 708-711 1988.

Spindler, M., and G.S. Dieckmann, Distribution and abundance of the Planktonic Foraminifer Neogloboquadrina pachyderma in sea ice of the Weddell Sea (Anarctica), Polar Biol., 5, 185-191, 1986.

Stuiver, $M$., and $\mathrm{P}$. Reimer, Extended ${ }^{14} \mathrm{C}$ data base and revised CALIB $3.0{ }^{14} \mathrm{C}$ age calibration program, Radiocarbon, 35 , 215-230, 1993.

Thomas, E., L. Booth, M.A. Maslin, and N. J. Shackleton, Northeastern Atlantic benthic foraminifera during the last 45,000 years: Changes in productivity as seen from the bottom up, Paleoceangraphy, this issue, 1995

Tolderlund, D.S., and A.W.H. BE, Seasonal distributions of planktonic foraminifera in the western North Atlantic, Micropaleontology, 30, 241-260, 1971.

Weinelt, M.S., M. Sarnthein, E. Vogelsang, and H. Erlenkeuser, Early decay of the Barent Shelf Ice Sheetspread of stable isotope signal across the eastern Norwegian Sea, Nor. Geol. Tidssk., 71, 137-140, 1991.

Wely, P.K., The role of oceans in climatic change, Meteorol. Monogr., 8, 37-62, 1986.

M. A. Maslin and U. Pflaumann Geologisch-Paläontologisches Institut, Universität Kiel, Olshausenstraße 40, D-24098 Kiel, Germany M. A. Maslin Department of Geography, University College London (Email MMaslin@geog.ucl.ac.uk)

N. J. Shackleton, Godwin Laboratory, University of Cambridge, Free School Lane, Cambridge, CB 3RS, England.

(Received December 1, 1993; revised March 21, 1994; accepted November 16, 1994) 